\title{
Modelling the interactions of the hydrothermal mussel Bathymodiolus azoricus with vent fluid
}

\author{
Husson Bérengère ${ }^{1,}{ }^{*}$, Sarrazin Jozée ${ }^{1}$, Van Oevelen Dick ${ }^{2}$, Sarradin Pierre-Marie ${ }^{1}$, Soetaert Karline ${ }^{2}$, \\ Menesguen Alain ${ }^{3}$
}

1 IFREMER, Ctr Bretagne, REM EEP, CS10070, F-29280 Plouzane, France.

2 Univ Utrecht, Royal Netherlands Inst Sea Res NIOZ Yerseke, Dept Estuarine \& Delta Syst, POB 140, NL-4400 AC Yerseke, Netherlands.

${ }^{3}$ IFREMER, Ctr Bretagne, DYNECO PELAGOS, CS10070, F-29280 Plouzane, France.

* Corresponding author : Bérangère Husson, email address : berengere.husson@ifremer.fr

\begin{abstract}
:
In the 40 years since the discovery of the rich faunal community around hydrothermal vents, many studies have clearly shown that environmental conditions have a strong influence on species distribution in these habitats. Nevertheless, the mechanisms that determine the spatial and temporal dynamics of species' responses to vent conditions remain elusive. Metabolic studies to assess faunal interactions with vent fluid are particularly difficult to perform in the deep sea and are generally executed in isolation ex situ. Available data mainly concern foundation species, which visually dominate these ecosystems. This work uses a modelling approach to integrate biotic and abiotic data that have been acquired through the years on Eiffel Tower, a large sulphide edifice located on the Lucky Strike vent field on the Mid-Atlantic Ridge, and particularly on its dominant species, Bathymodiolus azoricus. A carbon-flux model was built using seven state variables: the biomass of mussels and their associated thiotrophic (SOX) and methanotrophic (MOX) symbionts and the ambient concentrations of oxygen, dihydrogen sulphide, methane and (particulate and dissolved) organic carbon. Temperature of the surrounding water and mussel density were the forcing variables in the system. Results showed no statistically significant differences between predicted and observed mussel biomass and estimates of energy partitioning within the mussel were in the range of available data.

Metabolic rates were generally rather low and greatly reduced by a temperature effect in the coldest samples. These low metabolic rates imply a long lifespan for B. azoricus. Simulations suggest that they would strongly hinder re-establishment and resilience of mussel biomass. However, because symbionts respond quickly to changes in vent fluid, mussels would be able to buffer strong variations in the hydrothermal fluid supply. The model showed that if mussels fed indifferently on both types of symbionts, coexistence of MOX and SOX cannot be reached, thereby likely favouring hypotheses of competition for space inside the mussel gills and/or a differential use of the production of each symbiont. Model predictions are highly dependent on current knowledge, and the results presented here highlight the need for more quantitative data on the biology of $B$. azoricus across different size classes, on its interactions with symbionts, and in varying environmental concentrations in its substrates.
\end{abstract}




\section{Highlights}

- A new carbon-flux model on Bathymodiolus azoricus is used to assess its interactions with the hydrothermal fluid. Optimization of unknown parameter reveals a high impact of temperature on metabolic rates, suggesting a long lifespan. Outputs from the model include estimations for a daily carbon budget, growth limiting factors and hypotheses testing. Simulations were attempted to address the response of a mussel assemblage to various disturbances in its environment. The model highlights the need to better understand the host-symbiont relationship.

Keywords : Carbon flux model, Bathymodiolus azoricus, Eiffel Tower, Foundation species, Energy partitioning, Environmental conditions, Biomass, Hydrothermal ecosystems 


\section{Introduction}

Hydrothermal vents are formed in areas where seawater penetrates the porous oceanic crust, heats up in contact with hot rocks and rises to the seafloor as hot emissions (up to $400^{\circ} \mathrm{C}$ ), rich in reduced compounds and heavy metals (Johnson and Tunnicliffe, 1985; Johnson et al., 1988b). In the plume of hydrothermal fluids, many reactions occur spontaneously or because of the activity of microorganisms. Some of these microorganisms use the energy from the reactions for primary production through chemosynthesis, supporting most of the food webs in hydrothermal ecosystems (Jannasch, 1995; Jannasch and Wirsen, 1979). The last 40 years of vent research has significantly increased our knowledge on the biology and ecology of the fauna living there. In most cases, dense faunal assemblages, visually dominated by a few invertebrate species, proliferate around fluid exits (Cuvelier et al., 2009; Govenar et al., 2005; Tsurumi and Tunnicliffe, 2001; Tunnicliffe et al., 1997). Their spatial and temporal patterns are tightly linked to the intensity (Gollner et al., 2010; Luther et al., 2001; Marsh et al., 2012; Podowski et al., 2010; Sarrazin et al., 1999) and variability (Cuvelier et al., 2011a; Johnson et al., 1988a; Podowski et al., 2010) of hydrothermal fluids. However, the mechanisms underlying the faunal response to this varying environment are still poorly understood. The need to better understand the functioning of vent communities is becoming more urgent as the industrial exploitation of sulphide deposits, formed by hydrothermal vent activity, is imminent.

Faunal response can be complex, and two types of interactions between hydrothermal species and their environment have to be considered. First, the hydrothermal fluids provide high concentrations of reduced compounds that may trigger high chemosynthetic primary production, potentially transferred up through the food web. Second, fluids are also characterized by high temperatures, high concentrations of potentially toxic compounds and high temporal variability (Barreyre et al., 2014; Johnson et al., 1988a). However, quantitative data on the biology of vent species and abiotic conditions are still scarce for hydrothermal ecosystems. Trophic networks have mainly been studied throughthe use of stable isotopes and fatty acids (Bergquist et al., 2007; Colaço et al., 2002; Conway et al., 1994; De Busserolles et al., 2009; Léveillé et al., 2005), but the high trophic opportunism of many hydrothermal species and the difficulty of obtaining isotopic signatures of the primary producers has limited the quantification and modelling of trophic flows through the entire ecosystem. Moreover, species tolerance to fluid physico-chemical characteristics have only occasionally been evaluated (Henry et al., 2008; Shillito et al., 2006) and very little is known about factors limiting faunal settlement. Most biological data from these habitats involve large invertebrates, which have a symbiotic association with bacteria (e.g. Bathymodiolus septemdierum, Alviniconcha sp. and Ifremeria nautilei, (Henry et al., 2008); Bathymodiolus azoricus, (Colaço et al., 2002; De Busserolles et al., 2009)). This association ensures unshared primary production (Cavanaugh et al., 1981; Felbeck, 1981; Fisher et al., 1989; Girguis et al., 2002; Girguis and Childress, 2006) and offers a potential supplementary defence against fluid toxicity (Powell and Somero, 1986, 1985). These invertebrate species are referred to as "foundation species", because they significantly affect the habitat with the 3D structures they provide, favouring colonization by a wide range of associated species (Govenar and Fisher, 2007). Dayton (1972), who coined the term "foundation species", suggested that the study of these species would be a simple and efficient way of understanding an ecosystem's dynamics. Modelling is a widely used tool in marine ecosystem studies to integrate available quantitative knowledge, test hypotheses and predict the evolution of a system (Fennel and Neumann, 2014). A well-known hydrothermal edifice of the Lucky Strike vent field (Mid-Atlantic Ridge) is Eiffel Tower, dominated by the foundation mussel $B$. azoricus. To better understand the mechanisms underlying mussel 
spatial and temporal dynamics, we used available data to build a model mimicking the interactions between a $B$. azoricus assemblage and its environment. The objectives of our model were to (i) provide an estimate of the mussel energy budget, to gain insight on exchanges with the surrounding environment; (ii) determine factors that limit mussel growth in a given environment; (iii)predict the evolution of biomass of a settling mussel assemblage after an almost complete removal (direct disturbance) and also (iv) determine the response of an established assemblage to a flow interruption (indirect disturbance). Here, we used modelling to highlight gaps in our knowledge and guide future experiments.

\section{Materials and methods}

\subsection{Ecological studies}

Since the discovery of the Lucky Strike vent field in 1992 (Langmuir et al., 1993), several research activities including 27 oceanographic cruises and the set-up of the EMSO-Azores observatory in 2010 (http://www.emso-fr.org/EMSO-Azores) have helped to compile a large amount of data on this particular area. The Eiffel Tower edifice is one of the most studied structures at Lucky Strike. It is visually dominated by the mussel Bathymodiolus azoricus (Cuvelier et al., 2009; Desbruyères et al., 2000; Van Dover et al., 1996) and a second assemblage dominated by shrimp in higher temperature areas has been identified (Sarrazin et al., 2015). Numerous studies on Bathymodiolus have shown that it probably owes its success to the presence of two phylotypes of symbionts in its large gills (Distel et al., 1995; Duperron et al., 2006; Fiala-Médioni et al., 2002): one that can produce organic carbon from the oxidation of methane (methanotrophic bacteria, MOX) and the other from the oxidation of sulphide (thiotrophic bacteria: SOX). This dual endosymbiosis, associated with a functional gut, gives the mussels high trophic plasticity, allowing them to survive across a wide range of environmental conditions (Fiala-Médioni et al., 2002; Page et al., 1991). Riou et al. (2008) observed that the carbon is first fixed by the bacteria and then transferred to the other mussel tissues, probably via intracellular digestion of the symbionts (Fiala-Médioni et al., 2002), as also observed in other deep-sea bivalves (Fisher and Childress, 1986; Streams et al., 1997). A recent study estimated that $B$. azoricus contributes on average to almost $90 \%$ of the total biomass on the Eiffel Tower edifice (Husson et al., 2017). In addition, $B$. azoricus exhibits properties specific to foundation species such as the provision of habitat through supplementary surfaces and complex 3D structure (Cuvelier et al., 2009; Desbruyères et al., 2000; Trask and Van Dover, 1999). However, its importance for the rest of the ecosystem is not well understood.

\subsection{Sampling}

This study used data from 15 sampling units collected during two cruises that took place in 2006 (MoMARETO, Sarradin and Sarrazin, 2006) and 2014 (MoMARSAT, Sarradin and Cannat, 2014), on the "Pourquoi pas?" research vessel, using the remotely operated vehicle (ROV) Victor 6000. During the MoMARETO cruise in 2006, 12 samples were collected (samples $\mathrm{C} 1$ to $\mathrm{C} 12$, mean mussel size from 20 to $78 \mathrm{~mm}$, sampling procedure in Sarrazin et al., 2015). Three additional samples of medium and large mussels were collected during the MoMARSAT 2014 cruise (samples14-2 to 14-4, mean mussel size from 35 to $58 \mathrm{~mm}$, sampling procedure in (Husson et al., 2017). During both cruises, temperature was measured prior to faunal sampling on several points over the assemblage. Mussel density, length-weight relationship and total surface area was reported for both cruises in (Husson et al., 2017). The mussel body carbon-to-dry-weight ratio was measured on mussels collected during a third cruise (MoMARSAT 2015, R/V Pourquoi pas? using the ROV Victor 6000, Khripounoff et al., 2017; Sarradin and Cannat, 2015). Two estimates of the biomass were calculated on each sample by (i) applying length-weight relationship on each measured 
mussel length (B1) or (ii) applying length-weight relationship on the mean length of the sampled assemblage and multiplying by density (B2).
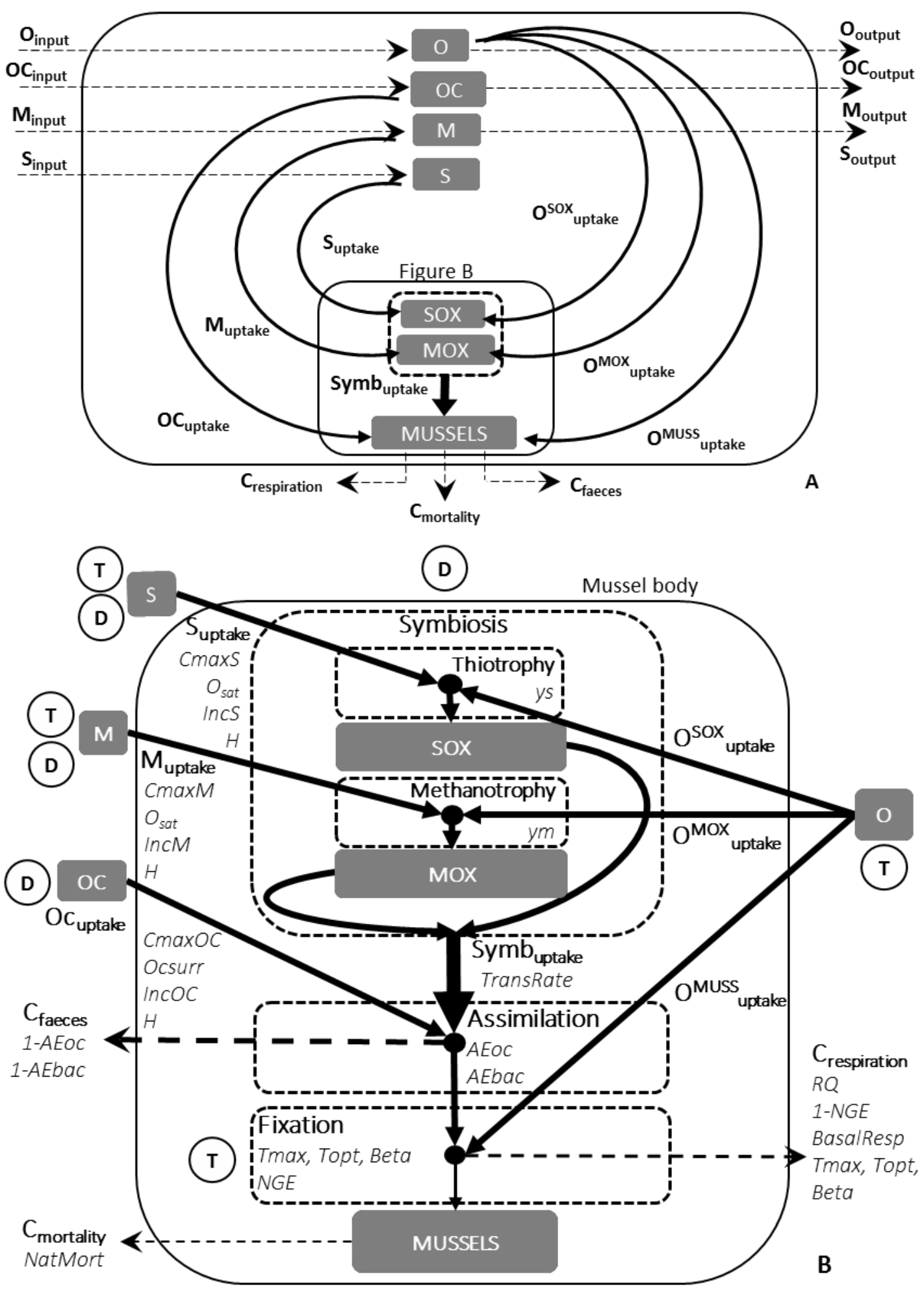

Figure 1. Conceptual model of the system including Bathymodiolus azoricus mussels, their symbionts and their environment. Grey boxes are state variables (Table 1) and dashed boxes describe processes. Solid arrows represent flows occurring inside the system and dashed arrows are flows entering or leaving the system (Table 2). A: system representation. The small box is the mussel body. B: Zoom on transfers that occur inside the mussel body. Italic texts are parameters of the model (Table 4). Black circles are forcing variables $T$ (temperature, ${ }^{\circ} \mathrm{C}$ ) and $\mathrm{D}$ (mussel density, ind $/ \mathrm{m}^{2}$ ). OCsurr is also a forcing variable but only influences $\mathrm{OC}_{\text {uptake }}$ 


\subsection{Model and equations}

The model represents a square meter of hydrothermal substratum containing mussels that are flushed with hydrothermal fluid. The model has seven state variables (Table 1, Figure 1): different potential food sources, i.e. particulate and dissolved organic carbon (OC in mol $\mathrm{OC} / \mathrm{L}$ ), methane ( $\mathrm{M}$ in mol $\mathrm{CH}_{4} / \mathrm{L}$ ), dihydrogen sulphide ( $\mathrm{S}$, in $\left.\mathrm{mol}_{2} \mathrm{~S} / \mathrm{L}\right)$, oxygen $\left(\mathrm{mol} \mathrm{O}_{2} / \mathrm{L}\right)$, mussel biomass (MUSSELS in $\mathrm{mol} \mathrm{C} / \mathrm{m}^{2}$ ) and their methanotrophic $\left(\mathrm{MOX}\right.$, in $\mathrm{mol} \mathrm{C} / \mathrm{m}^{2}$ ) and thiotrophic (SOX, in $\mathrm{mol} \mathrm{C} / \mathrm{m}^{2}$ ) symbionts.

Table 1. Name, definition and units of the model state variables.

\begin{tabular}{lll}
\hline State variable & Description & Unit \\
\hline MUSSELS & Mussel biomass & $\mathrm{mol} \mathrm{C} / \mathrm{m}^{2}$ \\
MOX & Methanotrophic symbiont biomass & $\mathrm{mol} \mathrm{C} / \mathrm{m}^{2}$ \\
SOX & Thiotrophic symbiont biomass & $\mathrm{mol} \mathrm{C} / \mathrm{m}^{2}$ \\
OC & Organic carbon concentration (particulate and dissolved) & $\mathrm{mol} \mathrm{OC} / \mathrm{L}$ \\
M & Methane concentration & $\mathrm{mol} \mathrm{CH} / / \mathrm{L}$ \\
S & Hydrogen sulphide concentration & $\mathrm{mol} \mathrm{H} \mathrm{H}_{2} / \mathrm{L}$ \\
O & Oxygen concentration & $\mathrm{mol} \mathrm{O} / \mathrm{L}$ \\
\hline
\end{tabular}

The model acts as a chemostat, where concentrations of chemical species are renewed by the incoming flow ( $\mathrm{O}_{\text {input }}, \mathrm{OC}_{\text {input }}, \mathrm{M}_{\text {input }}, \mathrm{S}_{\text {input, }}$ Table 2 ), consumed by the symbionts and mussels ( $\left.\mathrm{OC}_{\text {uptake, }} \mathrm{M}_{\text {uptake, }} \mathrm{S}_{\text {uptake, }} \mathrm{O}^{\mathrm{SOX}} \mathrm{x}_{\text {uptake, }} \mathrm{O}^{\mathrm{MOX}}{ }_{\text {uptake, }} \mathrm{O}^{\mathrm{MUSS}}{ }_{\text {uptake }}\right)$ and transported out of the system ( $\mathrm{O}_{\text {output, }} \mathrm{OC}_{\text {output }}, \mathrm{M}_{\text {output }}, \mathrm{S}_{\text {output)}}$ ). The SOX and MOX biomass increases as a result of thiotrophy - consuming oxygen ( $\mathrm{O}^{\text {sox }}$ uptake $)$ and hydrogen sulphides $\left(\mathrm{S}_{\text {uptake }}\right)-$ and methanotrophy - consuming oxygen and methane ( $\mathrm{O}^{\mathrm{MOX}}{ }_{\text {uptake }}$ and $\mathrm{M}_{\text {uptake }}$ respectively). Mussels feed on carbon obtained through filtration ( $\mathrm{OC}_{\text {uptake }}$ ) and symbiosis (Symbuptake), while respiration $\left(\mathrm{C}_{\text {respiration }}\right)$, production of faeces $\left(\mathrm{C}_{\text {faeces }}\right)$, and mortality $\left(\mathrm{C}_{\text {mortality }}\right)$ are loss terms.

Table 2. Names, definition and units of the flows included in the model.

\begin{tabular}{|c|c|c|}
\hline Name & Description & Unit \\
\hline \multicolumn{3}{|c|}{ Input flows in the system } \\
\hline$O C_{\text {input }}$ & Input of particulate and dissolved organic carbon & $\mathrm{mol} \mathrm{OC/L/d}$ \\
\hline Minput & Input of methane & $\mathrm{mol} \mathrm{CH}_{4} / \mathrm{L} / \mathrm{d}$ \\
\hline Sinput & Input of total dissolved sulphides & $\mathrm{mol} \mathrm{H} \mathrm{H}_{2} \mathrm{~S} / \mathrm{L} / \mathrm{d}$ \\
\hline Oinput & Input of oxygen & $\mathrm{mol} \mathrm{O}_{2} / \mathrm{L} / \mathrm{d}$ \\
\hline \multicolumn{3}{|c|}{ Consumption flows } \\
\hline OCuptake & Consumption of organic carbon by the MUSSELS & $\mathrm{mol} \mathrm{OC} / \mathrm{m}^{2} / \mathrm{d}$ \\
\hline Muptake & Consumption of methane by the MOX & $\mathrm{mol} \mathrm{CH} / 4 / \mathrm{m}^{2} / \mathrm{d}$ \\
\hline Suptake & Consumption of total dissolved sulphides by the SOX & $\mathrm{mol} \mathrm{H} \mathrm{H}_{2} \mathrm{~S} / \mathrm{m}^{2} / \mathrm{d}$ \\
\hline $\mathrm{O}^{\text {SOX }}$ uptake & Consumption of oxygen by the SOX & $\mathrm{mol} \mathrm{O}_{2} / \mathrm{m}^{2} / \mathrm{d}$ \\
\hline $\mathrm{O}^{\mathrm{MOX}}$ uptake & Consumption of oxygen by the MOX & $\mathrm{mol} \mathrm{O}_{2} / \mathrm{m}^{2} / \mathrm{d}$ \\
\hline OMUSS $_{\text {uptake }}$ & Consumption of oxygen by the MUSSELS & $\mathrm{mol} \mathrm{O}_{2} / \mathrm{m}^{2} / \mathrm{d}$ \\
\hline Symbuptake & Consumption of symbiotic production by the MUSSELS & $\mathrm{mol} \mathrm{C} / \mathrm{m}^{2} / \mathrm{d}$ \\
\hline \multicolumn{3}{|c|}{ Carbon loss flows } \\
\hline Cfaeces & Loss of non-assimilated carbon through faeces production & $\mathrm{mol} \mathrm{C} / \mathrm{m}^{2} / \mathrm{d}$ \\
\hline Crespiration & Loss of non-fixed carbon through respiration & $\mathrm{mol} \mathrm{C} / \mathrm{m}^{2} / \mathrm{d}$ \\
\hline Cmortality & Loss of carbon through mortality & $\mathrm{mol} \mathrm{C} / \mathrm{m}^{2} / \mathrm{d}$ \\
\hline \multicolumn{3}{|c|}{ Output flows } \\
\hline OCoutput & Output of particulate and dissolved organic carbon & $\mathrm{mol} \mathrm{OC/L/d}$ \\
\hline Moutput & Output of methane & $\mathrm{mol} \mathrm{CH}_{4} / \mathrm{L} / \mathrm{d}$ \\
\hline Soutput & Output of total dissolved sulphides & $\mathrm{mol} \mathrm{H} \mathrm{H}_{2} \mathrm{~S} / \mathrm{L} / \mathrm{d}$ \\
\hline Ooutput & Output of oxygen & $\mathrm{mol} \mathrm{O}_{2} / \mathrm{L} / \mathrm{d}$ \\
\hline
\end{tabular}


Table 3. List of conversion constants and conversion factors with independent variables shown in parentheses. DW: dry weight in g; WW: wet weight. L: straight shell length of a mussel in mm. T: surrounding temperature in ${ }^{\circ} \mathrm{C} .{ }^{1}$ : Riou et al. $(2008,2010),{ }^{2}:$ this study; ${ }^{3} \mathrm{Khripounoff}$ et al. (2017); ${ }^{4}$ Calculated from Posch et al., (2001) and Salerno et al., (2005); ${ }^{5}$ Duperron et al. (2016); ${ }^{6}$ Husson et al. (2017); ${ }^{7}$ Sarrazin et al., (2009); ${ }^{8}$ Slope of the theoretical dilution curve between the end-member and the seawater concentrations (Charlou et al., 2000) Value Definition

Unit

Conversion constants

MuscDW $^{1}$
GillDW $^{2}$
GillDW2GillWW $^{2}$ C2DW $^{3}$
Mol2dw
MolMOX $^{4}$
MolSOX

\subsection{9}

0.48

0.20

0.39

12/C2DW

$160 \times 10^{-15} / 12$

$7 \times 10^{-15} / 12$

Muscle DW to total flesh DW ratio

Gill DW to total flesh DW ratio

Gill DW to gill WW ratio

Carbon weight to total DW ratio

Ratio of total DW to moles of $C$ weight

1 MOX weight in moles $\mathrm{C}$

1 SOX weight in moles $\mathrm{C}$

\section{Shell length}

L (DW) ${ }^{2}$

$\mathrm{Nmax}(\mathrm{L})^{5}$

Surflnd $(L)^{2}$

MusselDW $(\mathrm{L})^{6}$

CurrentVel $(\mathrm{T})^{7}$

$\operatorname{ConcS}(T)^{8}$

$\operatorname{ConcM}(T)^{8}$ $\mathrm{e}^{4.16} \times \mathrm{DW}^{0.33}$

$6 \times 10^{7} \times L^{2.39}$

$e^{-13.682} \times L^{1.440}$

$e^{-12.21} \times L^{2.93}$

$(11.566 \times \mathrm{T}-7.8433) \times 86400 \times 10^{-3}$

$(6.5625 \times \mathrm{T}-26.25) \times 10^{-6}$

$(2.125 \times \mathrm{T}-8.5) \times 10^{-6}$

$(-0.7188 \times \mathrm{T}+232.88) \times 10^{-6}$
In gills

Surface occupied by one mussel

Mussel DW

Current velocity

Hydrogen sulphide concentration

Methane concentration

Oxygen concentration g DW muscle/g DW total

g DW gill/g DW total

g DW gill/g WW gill

g C/g DW total

$\mathrm{g} \mathrm{DW} / \mathrm{mol} \mathrm{C}$

$\mathrm{mol} \mathrm{C}$

$\mathrm{mol} \mathrm{C}$

\section{$\mathrm{mm}$}

$\mathrm{N}$ of symbionts

$\mathrm{m}^{2}$

g DW

$\mathrm{m} / \mathrm{d}$

$\mathrm{mol} / \mathrm{L}$

$\mathrm{mol} / \mathrm{L}$

$\mathrm{mol} / \mathrm{L}$ 
Table 4. Values of parameters used to initiate the optimization routine, with acronyms, definitions, units and reference: 1: Husson et al.(2017) and Sarrazin et al. (2015); 2: Empirically from Sarradin et al. (1999) and Pernet-Coudrier (unpublished data); 3 : (Dolmer, 2000; Edwards et al., 2005; Frechette et al., 1989); 4: Riou et al. (2010); 5: Riou et al. (2008); 6: Widdows et al. (1979); 7: Kochevar et al. (1992); 8:Henry et al. (2008); 9:

Empirically from Kochevar et al. (1992) and Scott and Cavanaugh, (2007); 10:Heijnen and Van Dijken, (1992); 11:Husson et al. (2017); 12: Barber and Blake (1985); 13: Mallet et al. (1987) and Comtet and Desbruyères, (1998); * optimized parameters.

\begin{tabular}{|c|c|c|c|c|}
\hline Name & Definition & Unit & Value & Ref. \\
\hline \multicolumn{5}{|c|}{ Parameters of input flows } \\
\hline $\mathrm{T}$ & Temperature (forcing parameter) & ${ }^{\circ} \mathrm{C}$ & Per sample & 1 \\
\hline OCsurr & Concentration of $\mathrm{OC}$ in surrounding water & $\mathrm{mol} \mathrm{OC/L}$ & 400 & 2 \\
\hline $\mathrm{H}$ & Water column height influenced by mussel uptake & $\mathrm{m}$ & 0.5 & 3 \\
\hline \multicolumn{5}{|c|}{ Parameters of uptake flows } \\
\hline IncPOC & Fixation rate of particulate organic carbon & $\mu \mathrm{mol} \mathrm{C} / \mathrm{g} \mathrm{dw}$ muscle/h & 0.29 & 4 \\
\hline IncDOC & Fixation rate of dissolved organic carbon & $\mu \mathrm{mol} \mathrm{C} / \mathrm{g} \mathrm{dw}$ muscle/h & 0.50 & 4 \\
\hline IncM & Fixation rate of methane & $\mu \mathrm{mol} \mathrm{C} / \mathrm{g} \mathrm{dw}$ gill $/ \mathrm{h}$ & 0.23 & 5 \\
\hline IncS & Fixation rate of sulphide & $\mu \mathrm{mol} \mathrm{C} / \mathrm{g} \mathrm{dw}$ gill/h & 0.37 & 5 \\
\hline uptM & Converter of fixation to uptake rates of methane & mol $\mathrm{CH}_{4}$ uptaken/mol C fixed & 10 & * \\
\hline uptS & Converter of fixation to uptake rates of sulphides & $\mathrm{mol} \mathrm{H}_{2} \mathrm{~S}$ uptaken/mol C fixed & 10 & * \\
\hline $\mathrm{CmaxOC}$ & Concentration of $\mathrm{OC}$ when maximal uptake occurs & $\mathrm{mol} \mathrm{OC/L}$ & $8 \times 10^{-3}$ & 6 \\
\hline CmaxM & Concentration of $\mathrm{M}$ when maximal uptake occurs & $\mathrm{mol} \mathrm{CH}_{4} / \mathrm{L}$ & $3 \times 10^{-4}$ & 7 \\
\hline Cmaxs & Concentration of $\mathrm{S}$ when maximal uptake occurs & $\mathrm{mol} \mathrm{H} \mathrm{H}_{2} \mathrm{~L}$ & $2 \times 10^{-4}$ & 8 \\
\hline Osat & Half-saturation constant for $\mathrm{O}_{2}$ & $\mathrm{~mol} \mathrm{O} / \mathrm{L}$ & $1.5 \times 10^{-4}$ & 9 \\
\hline \multicolumn{5}{|c|}{ Parameters controlling symbiont biomass } \\
\hline ym & Carbon gained from methane oxidation & $\mathrm{mol} \mathrm{C} / \mathrm{mol} \mathrm{CH}_{4}$ & 0.5 & 10 \\
\hline ys & Carbon gained from sulphide oxidation & $\mathrm{mol} \mathrm{C} / \mathrm{mol} \mathrm{H}_{2} \mathrm{~S}$ & 0.3 & 10 \\
\hline TransRate & Transfer of symbiotic carbon to the host & $/ d$ & 0.1 & * \\
\hline $\mathrm{D}$ & Density of mussels (forcing parameter) & $\operatorname{lnd} / \mathrm{m}^{2}$ & Per sample & 1 \\
\hline \multicolumn{5}{|c|}{ Parameters of mussel assimilation } \\
\hline AEoc & Assimilation efficiency of organic carbon & No unit & 0.7 & * \\
\hline AEbac & Assimilation efficiency of bacterial carbon & No unit & 0.99 & * \\
\hline \multicolumn{5}{|c|}{ Parameters of carbon fixation and loss in mussels } \\
\hline NGE & Efficiency of fixation of assimilated carbon & No unit & 0.4 & * \\
\hline Topt & Temperature with maximum metabolic rate & ${ }^{\circ} \mathrm{C}$ & 8.8 & 11 \\
\hline
\end{tabular}


Tmax

Beta

$\mathrm{RQ}$

BasalResp

NatMort
Upper thermal limit of metabolic activity

Shape coefficient of the temperature correction

Respiratory quotient

Basal respiration

Natural mortality rate
${ }^{\circ} \mathrm{C}$

No unit

$\mathrm{mol} \mathrm{C} / \mathrm{mol} \mathrm{O}_{2}$

/d

/d
20

0.5

0.9

0.001

$2.7 \times 10^{-4}$ 
The processes were constrained insofar as possible by data and conversion factors (listed in Table 3). Initial estimates of the model parameters were taken from the literature and available data (Table 4). The height of the system $(\mathrm{H}$, in $\mathrm{m}$, Table 4) was defined as the height of the water column the mussels have access to. We used parameters measured on the Eiffel Tower edifice, on B. azoricus, or in the deep sea, except for those determining filtration rates and mortality, which were mainly taken from studies on coastal mussels (Tables 3 and 4). Unknown parameters were tweaked to fit the model to the observed data as best as possible (see §2.4). Forcing variables were based on available data (see Figure 1, listed in Table 4). We imposed temperature $\left(T\right.$, in ${ }^{\circ} \mathrm{C}$ ) and mussel density ( $D$, in ind $\left./ \mathrm{m}^{2}\right)$, which were measured for each sample. Temperature was used as a proxy of hydrothermal fluid and forces environmental variables, such as current velocity or input flows, and enzymatic activity. Density was used to control the growth of symbionts and mussels and is assumed to be constant over time

Input and output flows (OC $\left.C_{\text {input }}, M_{\text {input, }} S_{\text {input, }} O_{\text {input }}\right)$ : Input flows were calculated by multiplying inputconcentrations by the ratio of flow through the system to the system volume. Input concentrations were estimated from linear relationships predicting the concentrations of each element as a function of temperature (Charlou et al., 2000) (ConcS (T), ConcM (T) and ConcO2 (T), Table 3). As no such relationship is available for organic carbon along the gradient, measured values of organic carbon above mussel assemblages were used (OCsurr, Table 4). The flow was estimated by multiplying current velocity by the entrance section of the system (Table 5). Current velocity $(\mathrm{m} / \mathrm{d})$ is determined using the current velocity/temperature relationship as measured by Sarrazin et al., (2009). The output flows were similarly estimated by multiplying the concentrations of the substances in the model by the ratio of flow to the system volume (Table 5).

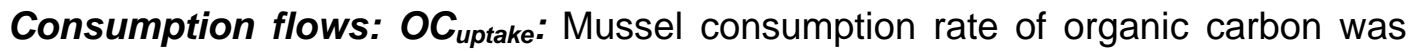
estimated usingfixation rates of POC and DOC available in the literature (Riou et al., 2010). Details for the calculations are shown in Appendix A. Resulting maximum uptake rate of organic carbon was named MaxUptOC. This uptake is limited by the organic carbon, following a Holling type II functional response (half-saturation constant $\mathrm{CmaxOC} / 2$ in mol $\mathrm{OC} / \mathrm{m}^{2}$, Table 4). The carrying capacity of mussels was also applied so that as the biomass of mussel increases, individual growth decreases, representing competition for space and food (Frechette et al., 1992; Frechette and Lefaivre, 1990). The carrying capacity for the mussels was set by the space occupied in the $1 \mathrm{~m}^{2}$ space of the system. To this end, the surface occupied by one individual (Surflnd, in $\mathrm{m}^{2} / \mathrm{ind}$, Table 3) was multiplied by the density. The individual surface was calculated from a relationship wath mean individual length ( $\mathrm{L}$, in $\mathrm{mm}$, Table 3), which was calculated from mussel biomass (MUSSELS, in $\mathrm{mol} \mathrm{C} / \mathrm{m}^{2}$, Table 1) and density ( $D$, ind $/ \mathrm{m}^{2}$, Table 4$)$ using a length-weight relationship to infer length from resulting individual mean weight (Table 3 ).

Consumption flow: $\boldsymbol{M}_{\text {uptake }}$ and $\boldsymbol{S}_{\text {uptake: }}$ Consumption of methane and dihydrogen sulphide was estimated using fixation (incorporation) rates from the literature, as shown in Appendices $B$ and $C$, giving a maximum uptake rate of methane, MaxUptM, and dihydrogen sulphide MaxUptS. Uptake of oxygen, dihydrogen sulphide and methane is limited by these substances, using Holling type II dynamics and, like OC uptake, by the carrying capacity of the mussel. The model also assumes a maximum carrying capacity for the symbionts, following the same principle as mussel carrying capacity, but using the maximum number of symbionts in the gills (Nmax, Table 3 ) instead of the maximum surface they occupy. 
Table 5: Summary of equations, showing only their state variables (in caps), parameters and conversion factors. SV: state variable. Nota bene: successive lines of one SV variation should be read as one equation, and parenthesis opened on one line can be closed in a lower one.

\begin{tabular}{|c|c|c|}
\hline SV variation & Components & Description \\
\hline \multirow[t]{6}{*}{$\frac{d M U S S E L S}{d t}=$} & $\left(M U S S E L S \times \frac{\operatorname{IncPOC} \times C 1 \times \max O C}{C P O C}+\frac{\operatorname{IncDOC} \times C 1 \times C \operatorname{maxOC}}{C D O C} \times \frac{O C}{O C+C \max O C / 2}\right.$ & $\begin{array}{l}\text { Limited fixation of carbon from } \\
\text { surrounding water }\end{array}$ \\
\hline & $\times\left(1-\operatorname{SurfInd}\left(\right.\right.$ MeanLength $\left.\left.\left(\frac{\text { MUSSELS } \times \text { Mol2dw }}{D}\right)\right) \times D\right)$ & $\begin{array}{l}\text { Uptake limited by mussel carrying } \\
\text { capacity }\end{array}$ \\
\hline & $+(M O X+S O X) \times A E b a c \times N G E \times$ TransRate & Fixation of carbon from symbiosis \\
\hline & - BasalResp $\times$ MUSSELS) & Loss of carbon through basal respiration \\
\hline & $\times\left(\frac{\text { Tmax }-T}{\text { Tmax }- \text { Topt }}^{\text {Beta }}\right) \times \exp \left(-\right.$ Beta $\left.\times \frac{\text { Tmax }-T}{\text { Tmax }- \text { Topt }}\right)$ & Kinetics rate corrected for temperature \\
\hline & - NatMort $\times$ MUSSELS & Loss of carbon through mortality \\
\hline \multirow[t]{4}{*}{$\frac{d S O X}{d t}=$} & $\begin{aligned}\left(\text { uptS } \times \gamma s \times \frac{\text { CmaxS } \times \frac{\operatorname{IncS} \times C 2 \times \text { MusselDW }(\text { sizeS }) / \text { Mol2dw }}{(\text { Nmax }(\text { sizeS }) \times \text { MolMOX } / \text { surf }) \times \text { propSOX }}}{C S} \times \frac{O}{O+O_{\text {sat }}}\right. \\
\times \frac{S}{S+C \operatorname{maxS} / 2} \times \operatorname{SOX}\end{aligned}$ & $\begin{array}{l}\text { Limited fixation of carbon from } \\
\text { thiotrophy }\end{array}$ \\
\hline & 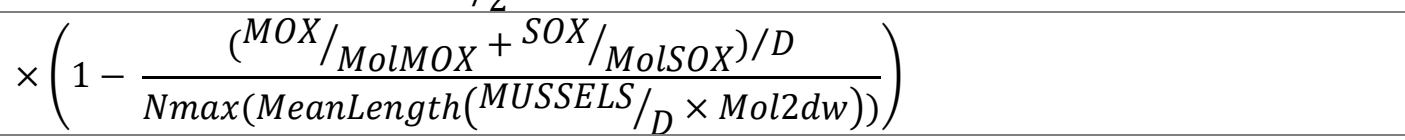 & $\begin{array}{l}\text { Uptake limited by symbiont carrying } \\
\text { capacity }\end{array}$ \\
\hline & $\times(1-\operatorname{SurfInd}($ MeanLength $($ MUSSELS $\times$ Mol2dw $/ D)) \times D))$ & $\begin{array}{l}\text { Uptake limited by mussel carrying } \\
\text { capacity }\end{array}$ \\
\hline & - SOX $\times$ TransRate & Loss of carbon through symbiosis \\
\hline \multirow{3}{*}{$\frac{d M O X}{d t}=$} & CmaxM $\times \frac{\operatorname{IncM} \times C 2 \times \text { MusselDW }(\text { sizeM }) / \text { Mol2dw }}{(\text { Nmax }(\text { sizeM }) \times \text { MolMOX } / \text { surfM }) \times \text { propMOX }}$ & \\
\hline & $\times \frac{M}{M+C \max M / 2} \times M O X$ & $\begin{array}{l}\text { Limited fixation } \\
\text { methanotrophy }\end{array}$ \\
\hline & 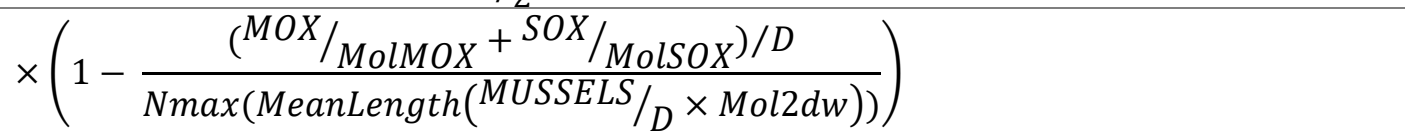 & $\begin{array}{l}\text { Uptake limited by symbiont carrying } \\
\text { capacity }\end{array}$ \\
\hline
\end{tabular}




\section{SV variation Components}

$\times(1-\operatorname{SurfInd}($ MeanLength $(M U S S E L S \times \operatorname{Mol2dw} / D)) \times D))$

- MOX $\times$ TransRate

\begin{tabular}{|c|c|}
\hline$d O C$ & OCsurr $\times$ CurrentVel $(T)$ \\
\hline$d t$ & $-O C \times$ CurrentVel $(T)$ \\
\hline & $-\frac{O C_{\text {uptake }}}{H \times 1 e-3}$ \\
\hline
\end{tabular}

$\frac{\boldsymbol{d} \boldsymbol{M}}{\boldsymbol{d t}}=\frac{\operatorname{ConcM}(T) \times \operatorname{CurrentVel}(T)}{-M \times \operatorname{CurrentVel}(T)}$

$-M \times$ CurrentVel $(T)$

$-\frac{M_{\text {uptake }}}{H \times 1 e-3}$

$\frac{\boldsymbol{d} \boldsymbol{S}}{\boldsymbol{d} \boldsymbol{t}}=\frac{\operatorname{ConcS}(T) \times \operatorname{CurrentVel}(T)}{-S \times \operatorname{CurrentVel}(T)}$

$-\frac{S_{\text {uptake }}}{H \times 1 e-3}$

dO $\quad \operatorname{ConcO}(T) \times$ CurrentVel $(T)$

$\overline{\boldsymbol{d} \boldsymbol{t}}=\quad-O \times \operatorname{CurrentVel}(T)$

$-\frac{\left(O^{\text {SOX }}{ }_{\text {uptake }}+O^{\text {MOX }}{ }_{\text {uptake }}+O^{\text {MUSS }}{ }_{\text {uptake }}\right)}{H \times 1 e-3}$

$H \times 1 e-3$

\section{Description}

Uptake limited by mussel carrying capacity

Loss of carbon through symbiosis

Input organic carbon flow

Output organic carbon flow

Mussel consumption of organic carbon

through filtration

Input methane flow

Output methane flow

MOX consumption of $M$ through

methanotrophy

Input sulphide flow

Output sulphide flow

SOX consumption of $S$ through thiotrophy

Input oxygen flow

Output oxygen flow

SOX, MOX and mussel consumption of oxygen through respiration 
Consumption flow: Oxygen uptakes: Oxygen uptake was determined by stoichiometry. The stoichiometric ratio between oxygen uptake vs. sulphide and methane uptake is $1: 2$, and the organic-carbon-to-consumed-oxygen ratio ( $R Q$, Table 4$)$ is usually between 0.8 and 1 ( $\mathrm{mol} \mathrm{C} / \mathrm{mol} \mathrm{O}_{2}$, e.g. Barber and Blake, (1985).

Symbiont dynamics: The biomass of the MOX and SOX increases via methanotrophy $\left(\mathrm{M}_{\text {uptake }}\right.$ and $\mathrm{O}^{\mathrm{MOX}}$ uptake$)$ and thiotrophy ( $\mathrm{S}_{\text {uptake }}$ and $\left.\mathrm{O}^{\mathrm{SOX}} \mathrm{x}_{\text {uptake }}\right)$, respectively, and decreases via

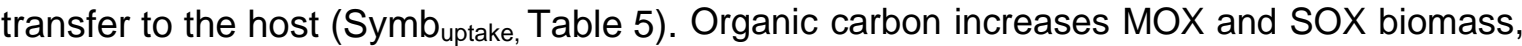
with a yield ym (in $\mathrm{mol} \mathrm{C} / \mathrm{mol} \mathrm{CH}_{4}$, Table 4) and ys (in $\mathrm{mol} \mathrm{C} / \mathrm{mol} \mathrm{H}_{2} \mathrm{~S}$, Table 4), respectively. A fixed proportion of the symbiontbiomass is transferred each day to the mussel (TransRate in /d, Table 4- Figure 1B). A strong assumption here was that the host feeds indifferently on both types of symbionts.

Mussel dynamics: Mussels grow through the uptake of organic matter from the water $\left(\mathrm{OC}_{\text {uptake }}\right)$ and from the symbionts (Symb $\mathrm{butake}_{\text {e }}$, Figure $\left.1 \mathrm{~A}\right)$. Carbon is assimilated via symbiosis with efficiency AEbac and via organic carbon in the water with efficiency AEoc (Table 4), and non-assimilated carbon is released as faeces $\left(\mathrm{C}_{\text {faeces }}\right)$. Assimilated carbon is then fixed with an efficiency NGE (net growth efficiency, Table 4), which was corrected for the temperature of the surrounding water, accounting for the influence of temperature on enzymatic activity (Clarke and Fraser, 2004) and on bivalve growth and respiration (Anestis et al., 2007; Newell, 1969; Widdows, 1973). The model used a correction factor (Blanchard et al., 1996) that requires only three parameters: the optimal temperature for growth (Topt in ${ }^{\circ} \mathrm{C}$, Table 4), the maximal temperature of survival (Tmax, in ${ }^{\circ} \mathrm{C}$, Table 4) and a coefficient of shape of the correction curve (Beta, no unit, Table 4). Non-fixed carbon and carbon used for basal metabolic maintenance (known as basal respiration, BasalResp in /d, Table 4) are released as $\mathrm{CO} 2$ ( $\left.\mathrm{C}_{\text {respiration}}\right)$. This rate was also corrected for temperature. Mortality $\left(\mathrm{C}_{\text {mortality }}\right)$ includes all other carbon losses (predation, natural mortality, disease, parasitism...). Little is known about mussel mortality at vents. The model assumed a fixed death rate per day (NatMort, Table 4), corresponding to an approximate loss of $10 \%$ of the biomass per year, which is the minimum observed in natural coastal mussel communities (Mallet et al., 1987 ) and corresponds to an estimated life span of approximately 10 years (Comtet and Desbruyeres, 1998).

\subsection{Calibration}

The model was implemented and solved in R (R Core Team, 2015) using the 'deSolve' (Soetaert et al., 2010) and 'rootSolve' packages (Soetaert and Herman, 2008). Some parameters for which no data were available were obtained by fitting the model against the 15 biomass data points (12 from MoMARETO and 3 from MoMARSAT), using the R-package FME (Soetaert and Petzoldt, 2010).

Assuming that these biomass values represent equilibrium conditions, which would be consistent with the status of climax community of mussel assemblages on Eiffel Tower (Cuvelier et al., 2011b), they were compared with the steady-state conditions generated by the model. A sensitivity analysis identified the parameters that were influencing mussel biomass the most. Then, pairwise correlations and global parameter colinearity estimates were used to remove highly correlated parameters (Table 6). Finally, the FME optimization routine sought values for these parameters within the imposed literature range (Table 6). 
Table 6. Range of parameters explored for model optimization. uptS and uptM in mol C fixed $/ \mathrm{mol} \mathrm{H}_{2} \mathrm{~S}$ uptaken and $\mathrm{mol} \mathrm{C}$ fixed/mol $\mathrm{CH}_{4}$ uptaken, respectively. TransRate, AEoc, AEbac, NGE and BasalResp in /d. Initial values (also shown in Table 4) shown in parentheses.

\begin{tabular}{|c|c|c|c|}
\hline Parameter & $\begin{array}{l}\text { Range (initial } \\
\text { value) }\end{array}$ & Reference or justification & Unit \\
\hline uptS & 1 to $2000(10)$ & \multirow{2}{*}{$\begin{array}{l}\text { Assuming an ecological } \\
\text { efficiency of } 10 \% \text { (Turner, 1970) }\end{array}$} & mol $\mathrm{H}_{2} \mathrm{~S}$ uptaken/mol C fixed \\
\hline uptM & 1 to $2000(10)$ & & $\mathrm{mol} \mathrm{CH}_{4}$ uptaken $/ \mathrm{mol} \mathrm{C}$ fixed \\
\hline TransRate & 0 to $1(0.1)$ & No data & $/ d$ \\
\hline AEoc & 0 to $0.89(0.7)$ & $\begin{array}{l}\text { (Thompson and Bayne, } \\
\text { 1972);(Page et al., 1991; } \\
\text { Welch, 1968) }\end{array}$ & $/ d$ \\
\hline AEbac & 0 to $1(0.99)$ & No data & $/ d$ \\
\hline NGE & $\begin{array}{l}0.15 \text { to } 0.77 \\
(0.4)\end{array}$ & $\begin{array}{l}\text { (Hamburger et al., 1983; } \\
\text { Kiørboe et al., 1981; Riisgård } \\
\text { and others, 1988; Riisgård and } \\
\text { Randløv, 1981) }\end{array}$ & $/ d$ \\
\hline Tmax & $\begin{array}{l}14.3 \text { to } 30^{\circ} \mathrm{C} \\
(20)\end{array}$ & $\begin{array}{l}\text { Husson et al. (2017); Sarrazin } \\
\text { et al. (2015) }\end{array}$ & $\mathrm{T}^{\circ} \mathrm{C}$ \\
\hline Beta & $\begin{array}{l}0.1 \text { to } 100 \\
(0.5)\end{array}$ & No data & No unit \\
\hline BasalResp & $\begin{array}{l}10^{-8} \text { to } 10^{-2} \\
\left(10^{-3}\right)\end{array}$ & $\begin{array}{l}\text { (Mahaut et al., 1995); } \\
\text { Stratmann et al. in prep }\end{array}$ & $/ d$ \\
\hline
\end{tabular}

The cost function in the optimization routine included two conditions: symbiont biomass should be non-null, and predicted mussel biomass had to be close to observed values. For mussel biomass, we used the mean values as determined from the two estimates (B1, better estimate of the real biomass, and B2, closer estimate of what the model would output); we assumed the error in the data to be $3 \mathrm{~mol} \mathrm{C} / \mathrm{m}^{2}$ (standard error between $\mathrm{B} 1$ and B2). For the symbionts, we assumed they occupied in average of $50 \%$ of gill surface, with an error of $20 \%$, which made it possible to discard models with no symbiotic biomass. The optimization was performed using the pseudo-random algorithm with 10,000 iterations and was followed by a Levenberg-Marquadt algorithm (Soetaert and Petzoldt, 2010).

A final sensitivity analysis was performed on the resulting model using the sensFun function (FME package) to identify parameters that strongly influenced the model outputs and thus to guide future scientific research.

\subsection{Simulations}

To further understand the dynamics of the interactions between mussels and their environment, the model was run to simulate two scenarios (direct and indirect disturbances) in two different environments: a cold environment, similar to the conditions around C9 (the sampling unit found in association with the coldest temperature, mean temperature: $4.9^{\circ} \mathrm{C}$ ) and a warm environment, similar to conditions measured around $\mathrm{C} 10$ (the warmest sampling unit, mean temperature: $8.8^{\circ} \mathrm{C}$ ). These two sampling units exhibited similar faunal densities (2435 ind// $\mathrm{m}^{2}$ for $\mathrm{C} 9$ and $2074 \mathrm{ind} . / \mathrm{m}^{2}$ for $\mathrm{C} 10$ ), so we used a density of $2200 \mathrm{ind} / \mathrm{m}^{2}$ for all simulations. The first scenario (direct disturbance) simulated the re-establishment of the community after partial removal of an assemblage of mussels, totalling 1 mole of carbon, in either a cold or warm environment. The aim was to determine when the stable state is reached. The second scenario (indirect disturbance) simulated flow interruptions of various durations for the coldest (C9) and warmest (C10) environments. These runs used the predicted stable states of the modelled biomasses of C9 andC10 as the initial state for the simulation. Flow interruption was simulated by decreasing 
surrounding temperature to that of ambient water $\left(4^{\circ} \mathrm{C}\right)$ and by withholding all inputs of organic carbon, methane and dihydrogen sulphide. This simulation was conducted for 100 , 200, 300 and400 days for each sample.

\section{Results}

\subsection{Model calibration and validation}

The best-fit parameters bringing the equilibrium conditions of the state values closer to the data are shown in Table 7. Optimized parameters for temperature correction led to a narrow bell-shaped curve (Figure 2), with fixation and respiration rates reduced to approximately $40 \%$ of their maximum in the coldest samples (e.g. C9, mean temperature $4.9^{\circ} \mathrm{C}$ ). Comparisons of mussel biomass and sulphide concentration showed a non-significant difference between the means of observed and modelled data ( $t$-test, $p=0.65, p=0.11$ and $p=0.82$ ). The predictive power of the model is less good for biomass $\left(R^{2}=0.1\right)$ than for total dissolved sulphide concentrations $\left(R^{2}=0.7\right)$. Regarding total dissolved sulphide, the model tends to overestimate final concentrations in the coldest samples and underestimate them in the warmest samples (Figure 3B).

Table 7. Final values of optimized parameters, i.e. changed from initial estimates (Table 6) to fit the sample-estimated biomasses

\begin{tabular}{ll}
\hline Parameter & Optimized value \\
\hline uptS & $1993 \mathrm{~mol} \mathrm{H} 2 \mathrm{~S}$ uptaken $/ \mathrm{mol} \mathrm{C}$ fixed \\
\hline uptM & $1362 \mathrm{~mol} \mathrm{CH}_{4}$ uptaken $/ \mathrm{mol} \mathrm{C}$ fixed \\
\hline TransRate & $0.048 / \mathrm{d}$ \\
\hline AEoc & $0.17 / \mathrm{d}$ \\
\hline AEbac & $0.98 / \mathrm{d}$ \\
\hline NGE & $0.79 / \mathrm{d}$ \\
\hline Tmax & $29.7^{\circ} \mathrm{C}$ \\
\hline Beta & 53.7 \\
\hline BasalResp & $7 \times 10^{-4} / \mathrm{d}$ \\
\hline
\end{tabular}

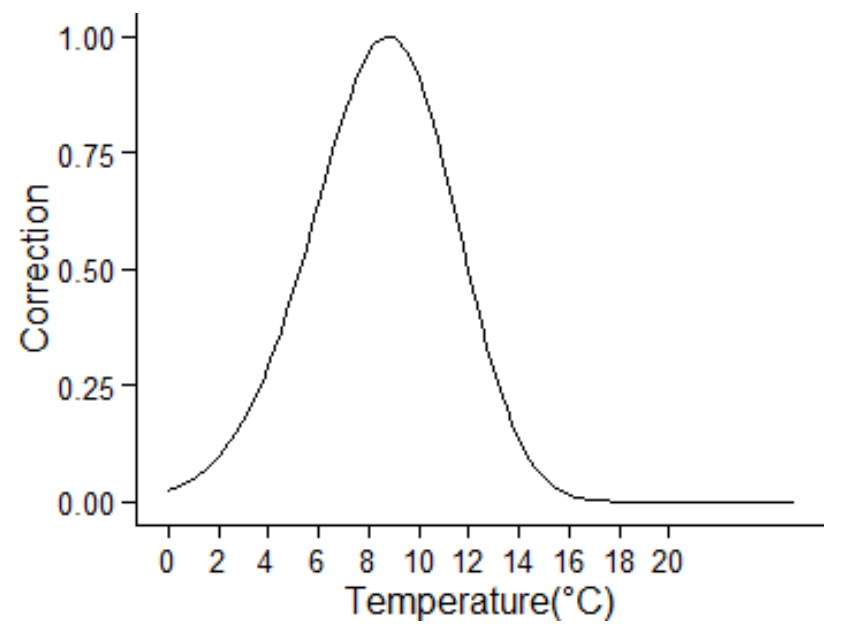

Figure 2. Curve of the correction of fixation and respiration for temperature, using the Blanchard et al. (1996) equation and the parameters Tmax $=29.7^{\circ} \mathrm{C}$, Beta $=53.7$ (Table 7) and Topt=8.8 (Table 4) 


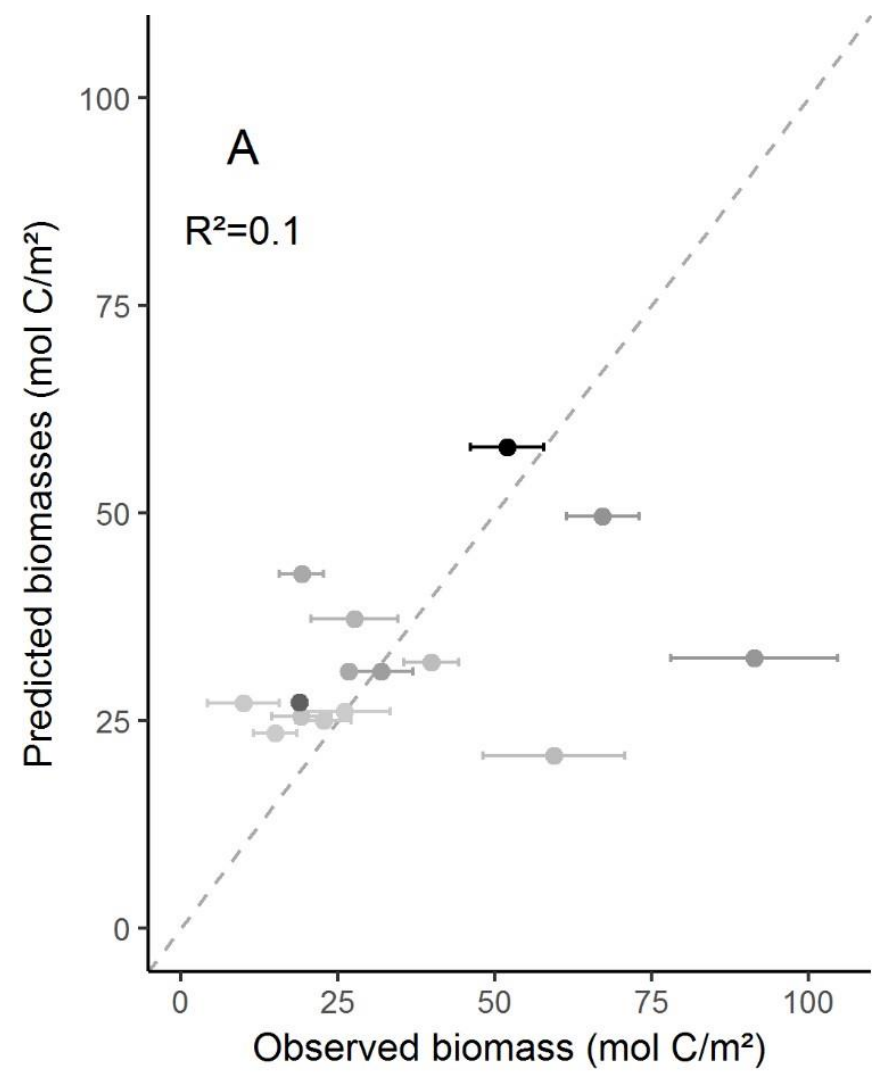

Figure 3. Predicted (y-axis) and observed (x-axis) (or estimated) coordinates of the 15 samples from MOMARETO 2006 and MoMARSAT 2014 cruises. Dotted lines show the 1:1 curve indicating equality between observed and predicted values. A: mussel biomass (mol $\mathrm{C} / \mathrm{m}^{2}$ ). Horizontal bars represent range between sample biomass estimates B1 (right end) and B2 (left end of the bar). Circles are the means of these two estimates, used to calibrate the model. B: modelled dihydrogen sulphide concentrations ( $\mu \mathrm{mol} \mathrm{H}_{2} \mathrm{~S} / \mathrm{L}$, y-axis) and observed total dissolved sulphide concentrations ( $\mu \mathrm{mol}$ $\mathrm{TdS} / \mathrm{L}, \mathrm{x}$-axis). No sulphide data were available for 14-4, 14-3 and 142 samples, hence the missing data.

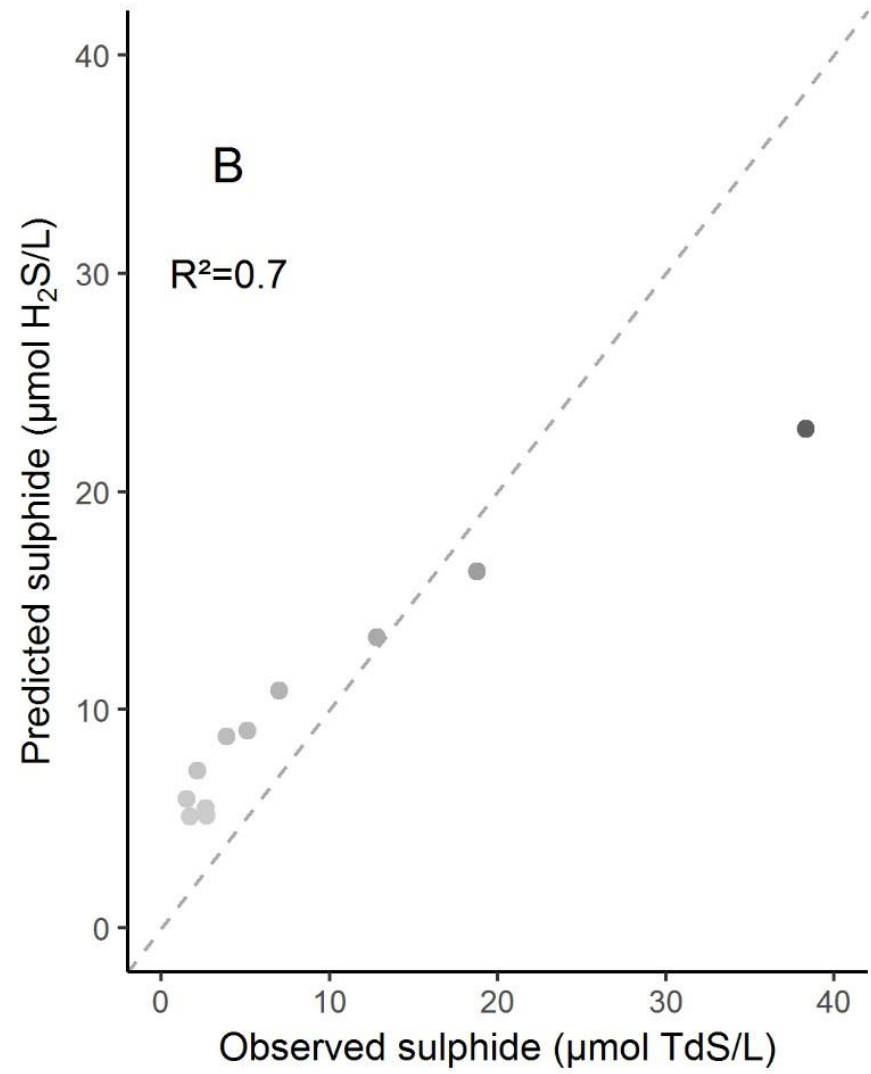

Temperature $\left({ }^{\circ} \mathrm{C}\right.$

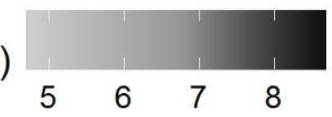




\subsection{Mussel carbon budget}

The first important result is that the model failed to reproduce the simultaneous presence of both symbionts. The MOX biomass predicted by the model is close to zero for all samples (mean \pm se:3.4 $\times 10^{-14} \pm 2.4 \times 10^{-14} \mathrm{~mol} \mathrm{C} \mathrm{MOX} / \mathrm{m}^{2}$ ) and, consequently, so is the uptake of methane $\left(9.2 \times 10^{-19} \pm 7.8 \times 10^{-19} \mathrm{~mol} \mathrm{CH}_{4} / \mathrm{mol} \mathrm{C} / \mathrm{d}\right)$. In contrast, SOX symbiont biomass reaches a mean of $0.8 \pm 0.08 \mathrm{molC} / \mathrm{m}^{2}$. The number of SOX per mussel, calculated from the predicted SOX biomass and their estimated individual weights (Table 3 ) varied between 2.4 $\times 10^{11}$ and $2.3 \times 10^{12} \mathrm{SOX} /$ mussel, thus reaching $95.5 \pm 1.7 \%$ of maximum gill carrying capacity.

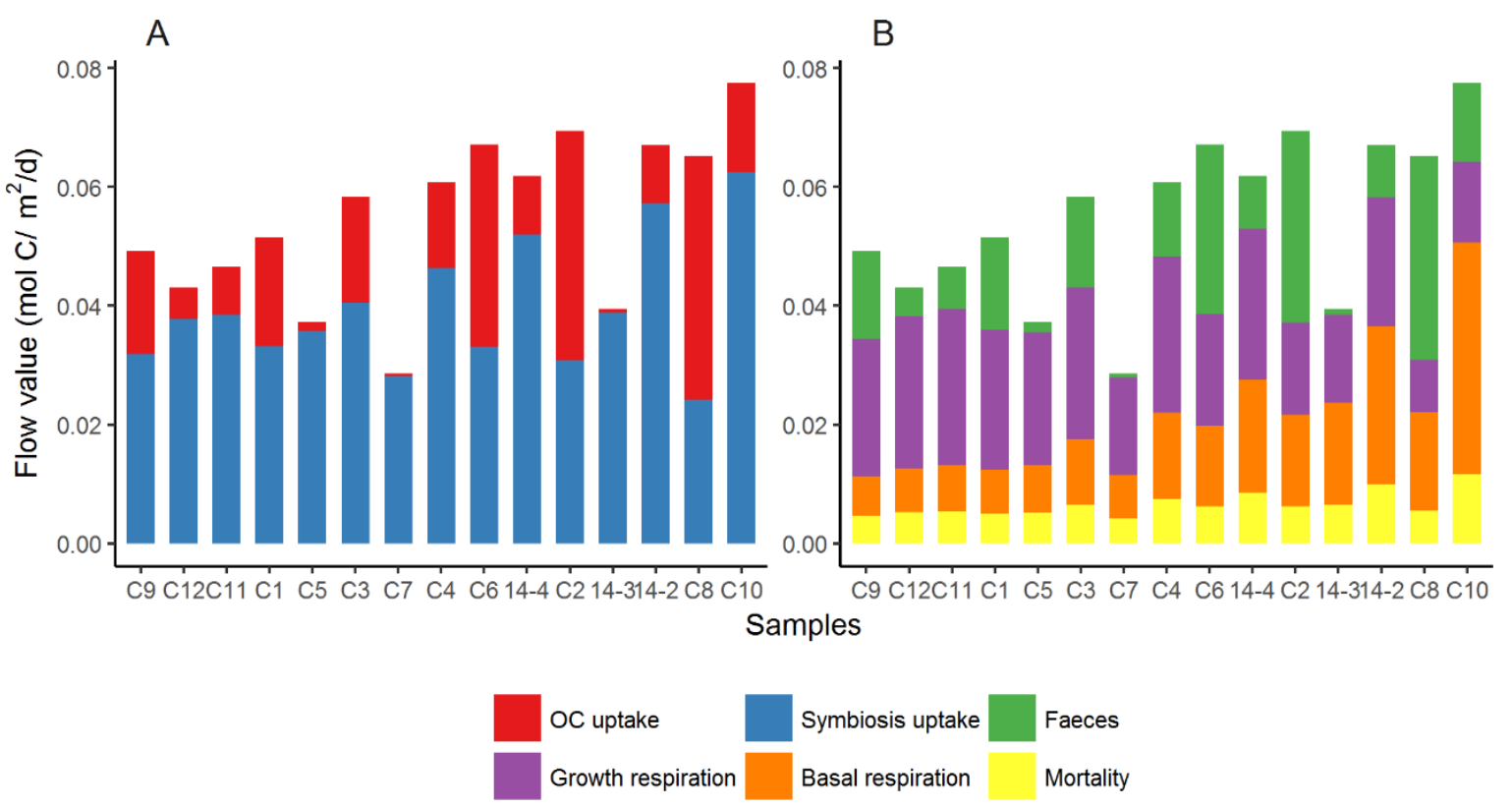

Figure 4. Carbon budget of the mussels in the system. A: input flows, B: output flows. Samples are ordered from the coldest habitat (left side) to the warmest one (right side). "Growth respiration" is the active respiration, corresponding to the cost of feeding activity. "Basal respiration" represents the respiration occurring constantly for organism maintenance.

Resulting uptake of dihydrogen sulphide by SOX ranged from $2.9 \mathrm{mmol} \mathrm{H}_{2} \mathrm{~S} / \mathrm{mol} \mathrm{C}$ of mussels/d in a warm sample (C8) to $4.8 \mathrm{mmol} \mathrm{H}_{2} \mathrm{~S} / \mathrm{mol} \mathrm{C/d}$ in a cold sample (C12). Contrastingly, the uptake of organic carbon (Figure 4, red) ranged from 17.4 to $1506 \mu \mathrm{mol}$ $\mathrm{OC} / \mathrm{mol} \mathrm{C} / \mathrm{d}$ (mean $504 \pm 1166 \mu \mathrm{mol} \mathrm{OC} / \mathrm{mol} \mathrm{C} / \mathrm{d}$ ) without a clear pattern along the temperature gradient. Mussel uptake of symbiotic carbon (Figure 4, blue) was almost three times higher than that of ambient organic carbon, with a mean of $1.23 \pm 0.04 \mathrm{mmol} \mathrm{C} / \mathrm{mol}$ $\mathrm{C} / \mathrm{d}$, representing on average $74.6 \pm 5.0 \%$ of mussel nutrition. Faeces production by mussels (Figure 4, green) was on average $433 \pm 99 \mu \mathrm{mol} \mathrm{C} / \mathrm{mol} \mathrm{C} / \mathrm{d}$, with no clear patterns along the temperature gradient. Respiration (growth plus basal respiration, Figure 4, in purple and orange) was the highest source of carbon loss for mussels in all samples, with a mean of $1.1 \pm 0.03 \mathrm{mmol} \mathrm{C} / \mathrm{mol} \mathrm{C} / \mathrm{d}$, decreasing from 1.3 to $0.9 \mathrm{mmol} \mathrm{C} / \mathrm{mol} \mathrm{C} / \mathrm{d}$ from the cold environment (small mussels) to the warm environment (large mussels). Similarly, the total mussel oxygen consumption through respiration and oxygen consumed through chemosynthetic reactions in symbionts, displayed a slightly decreasing trend, from 11.1 $\mathrm{mmol} \mathrm{O} / \mathrm{mol} \mathrm{C} / \mathrm{d}$ in a cold sample $(\mathrm{C} 12)$ to 10 to $12 \mathrm{mmol} \mathrm{O} / \mathrm{mol} \mathrm{C} / \mathrm{d}$ in the warmest sample $(14-2, \mathrm{C} 8, \mathrm{C} 10)$. Mortality was a fixed part of the biomass and did not vary between the samples. 


\subsection{Growth limitations}

Sulphide uptake rate was limited, ranging from $5 \%$ of the maximum in cold samples to $24 \%$ in warm ones (Figure 5, in green). The methane uptake rate was even more limited, only 1 to $6 \%$ of its maximum, following the same pattern as sulphide limitation (Figure 5 , in red). Contrastingly, because of the uniform organic carbon concentration used in the model, the uptake rate of organic carbon reached $5 \%$ of its maximum in all samples (Figure 5, in brown). Symbiotic uptake rates were evenly affected by the lack of oxygen, regardless of mussel size, and thus its position in the thermal gradient (Figure 5, in blue). They dropped to $60 \%$ of their maximum, andfinal concentrations ranged from $226 \mu \mathrm{mol} \mathrm{O} / 2 \mathrm{~L}$ in $\mathrm{C} 10$ to 229 $\mu \mathrm{mol} \mathrm{O}_{2} / \mathrm{L}$ in C9. Temperature correction (Figure 5, in purple) reduced fixation and respiration rates to $41 \%$ of their maximum value in the coldest samples and to $99 \%$ in the warmest ones. Mussel and symbiont carrying capacities strongly limited uptake rates. All uptake rates were more or less affected by mussel density along the temperature gradient: mussels occupied between 24 to $99 \%$ of the available surface, leading to uptake rates that were reduced from 1 to $76 \%$ of their maximum (Figure 5, in orange). Symbiotic uptake rates were limited by 82 to $99 \%$ by the symbiont density in the gills (Figure 5, in yellow).

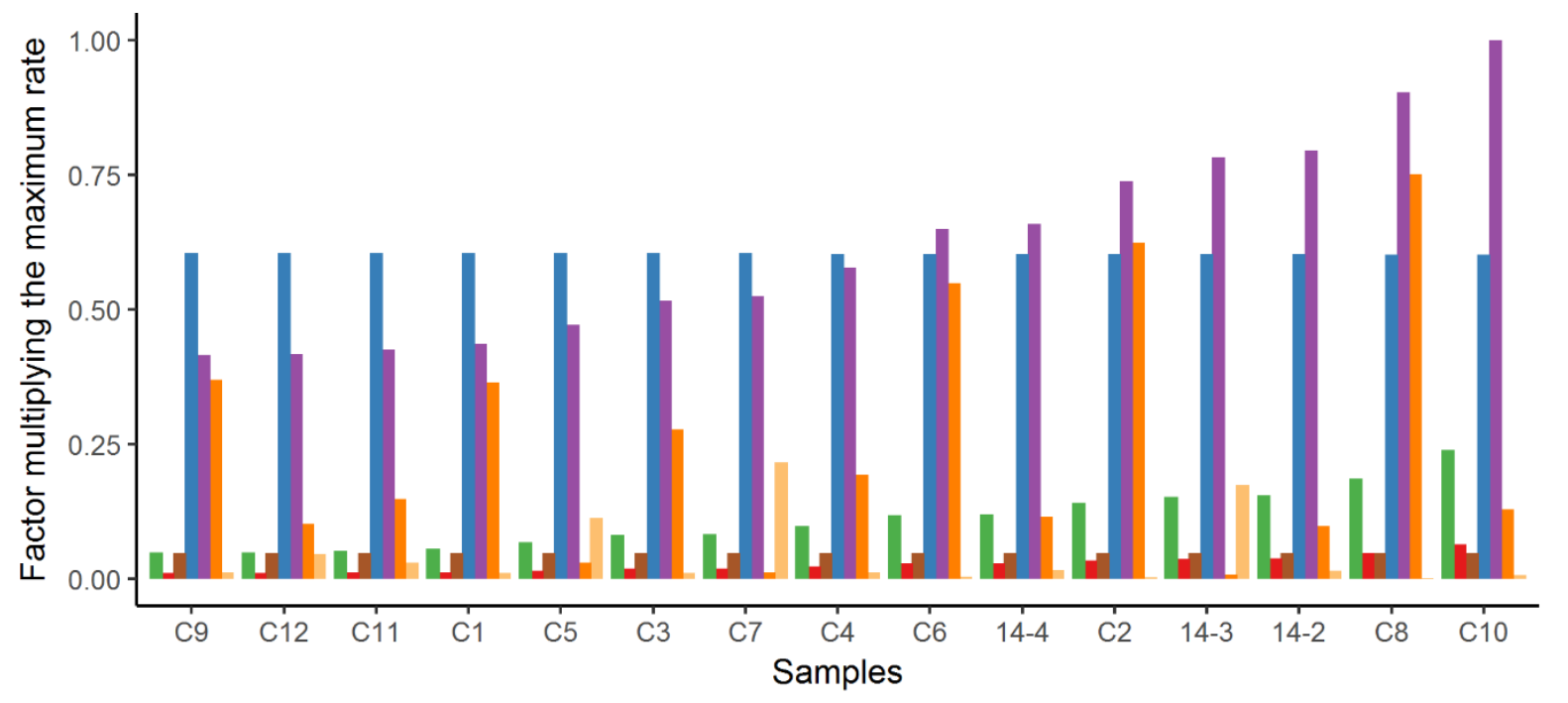

\begin{tabular}{|c|c|c|}
\hline Limitation by lack of hydrogen sulfide & Limitation by lack of methane & Limitation by lack of organic carbon \\
\hline Limitation by lack of oxygen & Effect of temperature & Mussels carrying capacity \\
\hline
\end{tabular}

Figure 5. Limitations and carrying capacities of the model. They have no unit and range from 0 to 1. Green: limitation of maximum SOX thiotrophy rate due to lack of dihydrogen sulphide. Red: limitation of maximum MOX methanotrophy rate due to lack of methane. Brown: limitation of maximum mussel filtration rate due to lack of organic carbon. Blue: limitation of maximum methanotrophy and thiotrophy rates due to lack of oxygen. Purple: correction of mussel fixation and respiration rates for the temperature effect on enzymatic reactions. Yellow: mussel carrying capacity: limitation of all maximum uptake rates due to mussel density. Orange: symbiont carrying capacity: limitation of symbiont uptake due to symbiont density. 


\subsection{Sensitivity analysis}

The model exhibited the highest sensitivity for the parameter describing the yield of thiotrophy(ys). Assimilation efficiency of organic carbon (AEoc), the shape parameter of the curve of the Blanchard's correction for temperature (Beta) and the conversion of carbon incorporation rates via thiotrophy (taken from the literature) into dihydrogen sulphide uptake rates (uptS) are also parameters for which small changes in their values caused large variations in model outputs. On the contrary, the rate of non-metabolic carbon loss (mortality, through parameter NatMort) and the height of the water column to which the mussels have access $(\mathrm{H})$ had low influences on model output.

\subsection{Dynamics of mussel interactions with vent fluid}

The first simulation (Figure 6) showed that a stable state is reached very slowly in cold and warm environments; taking about 23,400 days ( 64 years) in a cold environment (C9) and 12,100 days ( 33 years) in a warm environment (C10). Although both simulations were conducted with the same density of mussels $\left(2200 \mathrm{ind} / \mathrm{m}^{2}\right)$, temperature and associated environmental factors allowed different stable-state values of mussel biomass, with $57 \mathrm{~mol}$ $\mathrm{C} / \mathrm{m}^{2}$ in $\mathrm{C} 10$ and $22 \mathrm{~mol} \mathrm{C} / \mathrm{m}^{2}$ in $\mathrm{C} 9$.

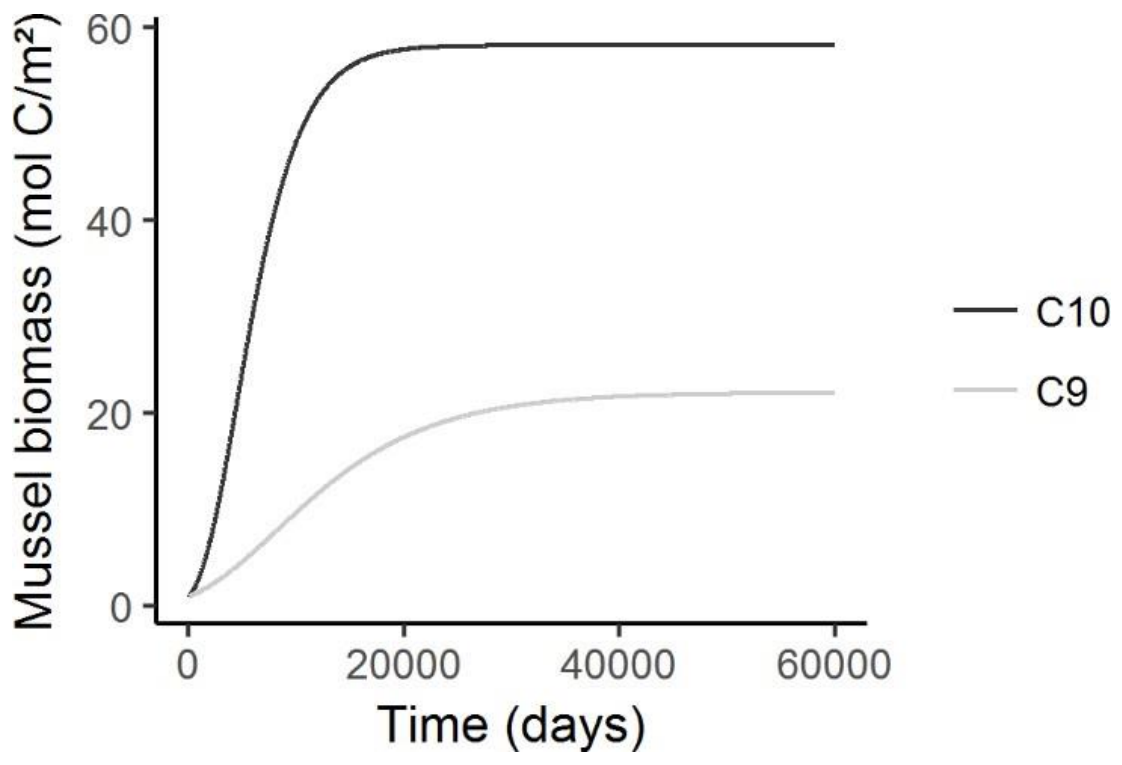

Figure 6. Direct disturbance simulation: re-establishment dynamics of a low biomass $\left(1 \mathrm{~mol} \mathrm{C} / \mathrm{m}^{2}\right)$ mussel assemblage in a cold (C9) and a warm habitat (C10) after partial removal of the fauna.

The second simulation (Figure 7) predicted the response of mussel biomass in the same sampling units to various modifications in hydrothermal fluid supply. In the cold sample (C9), dihydrogen sulphide concentrations decreased rapidly to $0 \mathrm{~mol} / \mathrm{L}$ after a flow interruption and immediately ( $<1$ day) returned to their initial concentrations when hydrothermal fluid flowed again. SOX biomass decreased by more than $99.9 \%$ in all simulations, whereas mussel biomass decreased much more slowly corresponding to a decrease of $3.3 \%$ in 100 days, $6.9 \%$ in 200 days and $14.2 \%$ in 400 days (Figure 7 ).

Following fluid flow interruptions varying from 100 to 400 days, SOX biomass in C9 reached 97.2 to $89 \%$ of their initial state after 300 days of recovery, but neither of these simulations completely recovered the stable state. Mussel biomass recovery in the cold sample was less 
than $0.1 \%$ of its initial state after 100 days of interruption, $0.3 \%$ after 300 days and $0.4 \%$ after 400 days. Similar results were observed in the warm sample C10, associated with higher concentrations of hydrogen sulphide, although recovery was slightly more efficient with SOX biomass reaching $97.8 \%$ of its initial value after a flow interruption of 100 days, $94.8 \%$ after 200 days, $92.2 \%$ after 300 days and $89.6 \%$ after 400 days. Similarly, mussel biomass recovery was slightly more efficient than in the cold sample with $0.3 \%$ of its initial value recovered after 300 days following a flow interruption of 100 days, $0.5 \%$ after 200 days, $0.8 \%$ after 300 days and $0.9 \%$ after a 400 days.

C9 (cold sample)
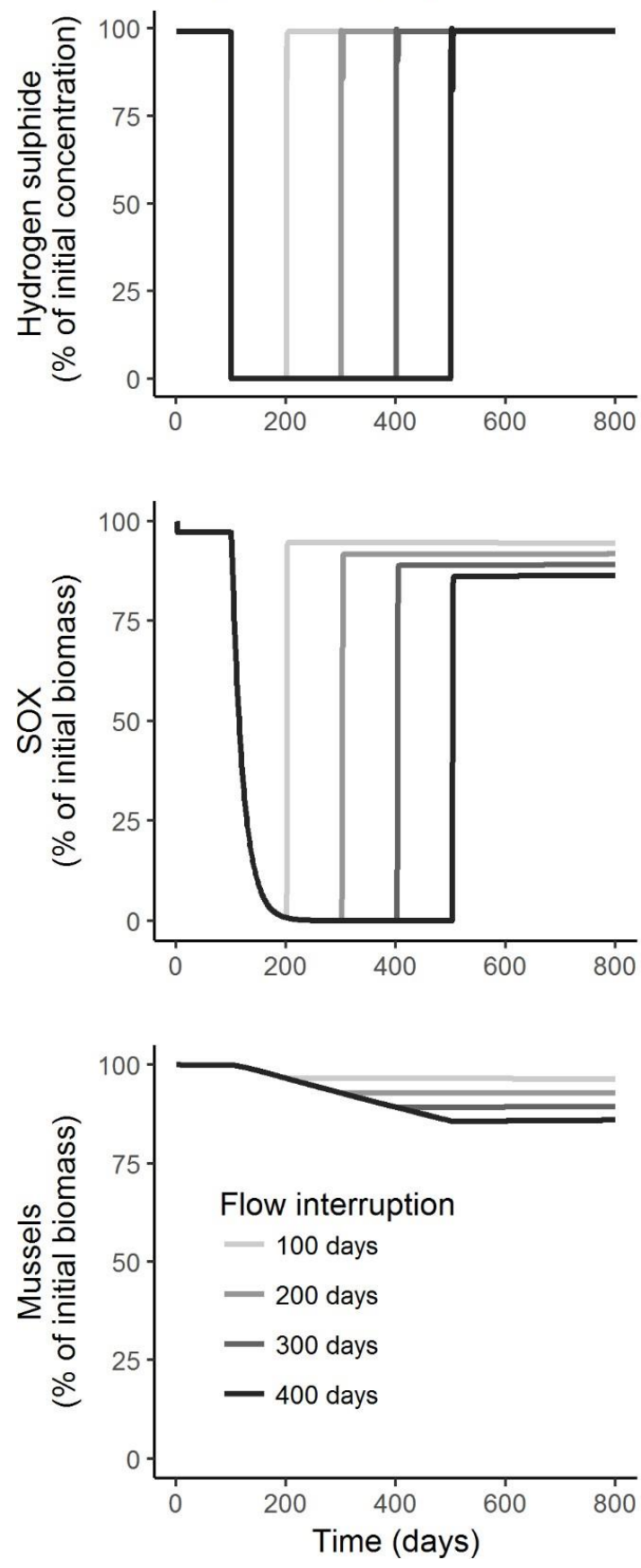

C10 (warm sample)
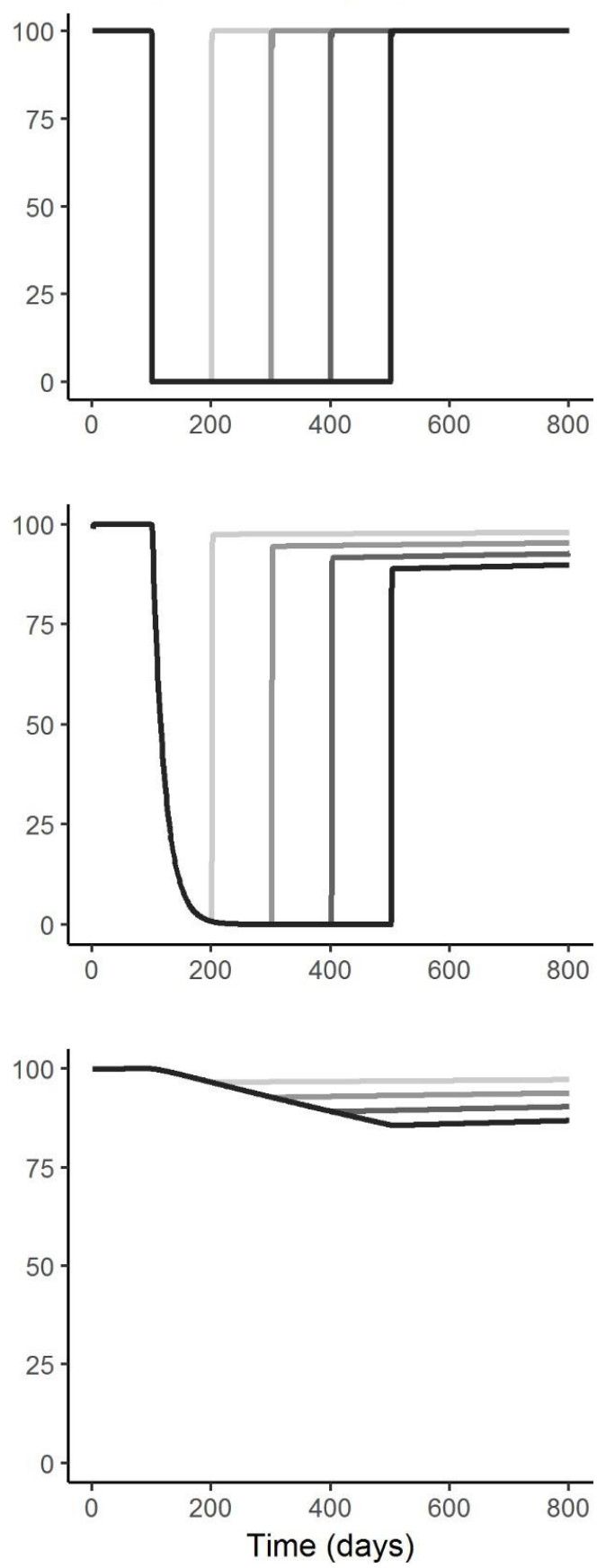

Figure 7. Indirect disturbance simulation: dihydrogen sulphide concentration as well as SOX and mussel biomass response to a flow interruption of 100, 200, 300 or 400 days. 


\section{Discussion}

This study explored the interactions of the deep-sea vent mussel Bathymodiolus azoricus with its environment using a modelling approach. A simple model was built, representing the trophic fluxes between mussels, their symbionts and their environment. The model provides valuable insights on species interactions with vent fluid and on mussel biology.

\subsection{Best fitting model}

Data used to constrain this model were extracted mainly from the literature on deepsea hydrothermal or cold-seep mussels (e.g. Bathymodiolus septemdierum, (Beinart et al., 2015; Henry et al., 2008); Bathymodiolus sp., (Kochevar et al., 1992); Bathymodiolus puteoserpentis, (Duperron et al., 2016)) and as much as possible from B. azoricus (e.g. Husson et al., 2017; Khripounoff et al., 2017; Riou et al., 2010, 2008; Salerno et al., 2005). However, it should be noted that very few data are available to estimate the uncertainties of each parameter. This model is a tool that allows to build hypotheses from up-to-date data and that can be updated with ongoing research.

The main data to constrain consumption flows were incorporation rates reported in Riou et al. $(2010,2008)$. Using conversion factors shown in Table3, these rates indicated that $0.0032 \%$ of carbon biomass is fixed daily through methanotrophy, $0.0131 \%$ through thiotrophy, $0.004 \%$ through filtration of particulate organic carbon and $0.0070 \%$ of dissolved organic carbon. To compensate for these low incorporation rates, the optimization routine selected low rates of basal respiration (reaching $0.0007 \%$ of carbon biomass per day), and the rest of the fixed carbon loss occurred through growth respiration, faeces production and mortality. These low metabolic rates were further constrained by the way fixation and respiration rates are limited by temperature, resulting in a narrow bell-shaped curve (parameters Tmax and Beta). Temperature thus has a potentially important effect on mussel metabolic activity, with mussels in cold habitats having metabolic rates approximately twice as low as in the warm habitats. This temperature effect may explain the spatial segregation of mussels according to size: the presence of smallermussels in the cold part of the mixing gradient may reflect lower growth rates compared with those closer to the vent influence. The temperature effect may have also affected the optimization routine trying to compensate for the lack of size-related metabolic data. Additional metabolic measurements on different mussel size classes could help understand the life cycle and spatial organisation of the species, because several metabolic rates such as uptake, growth and respiration are known to change with size (Hamburger et al., 1983; Speakman, 2005; Vahl, 1973; Widdows, 1978).

The mean of predicted biomasses was statistically similar to that of the observed biomasses, which is a very encouraging result. However, our model was unable to reproduce their variability. Several explanations can be considered. First, our model may exclude some factors potentially influencing mussel biomass. Temperature has been identified as a good proxy for several components in the hydrothermal fluid such as methane and sulphides (Cuvelier et al., 2011a; Sarradin et al., 1999), which are used by the symbionts of $B$. azoricus to increase in biomass. However, other compounds, such as hydrogen, can also be used by some hydrothermal mussels (Petersen et al., 2011), but were not included in the model. Also, elements not correlated with temperature, such as copper, may also influence mussel biomass. Indeed, it has already been suggested that mussel biomass may not directly respond to temperature in their natural habitat. For instance, a study along a thermal gradient (Husson et al., 2017) showed that there was no correlation between high biomass and high temperature. One explanation may be that the model considers a constant flow over the mussels, while the assemblages might actually experience periods of time with no 
hydrothermal flow because of current direction. Second, the carrying capacity term in the model only allowed one layer of mussels to occupy $1 \mathrm{~m}^{2}$, but in some places of the Eiffel Tower edifice, mussels can pile up in several layers (in sample 14-3 for example). Therefore, modifying the mussel carrying capacity in the model, as for example in Guiñez et al., (1999), may help the model reach higher biomasses. Also, allowing for higher carrying capacities would make the model applicable to other hydrothermal mussels such as $B$. septemdierum, which form dense multi-layered assemblages in the Pacific (e.g. Podowski et al., 2009). Third, for the sake of simplicity, the model did not take reproduction into account, although this may influence observed biomass temporally.

Finally, another possible reason for the weak fit between the modelled and observed biomass is linked to symbiont dynamics. Predicted methane uptakes were close to zero, because the biomass of MOX symbionts was very low, whereas the literature reports values of relative space or volume occupied by MOX ranging from 4 to $61 \%$ of the gills (Halary et al., 2008; Le Bris and Duperron, 2010; Riou et al., 2008; Szafranski et al., 2015). The carrying capacity of symbionts was controlled by a common model parameter: the maximal number of symbionts (MOX plus SOX) per mussel (Nmax). Despite the energetic advantage of methanotrophy (Heijnen and Van Dijken, 1992), the low concentrations of methane in the mussel habitat compared with that of dihydrogen sulphide favours the growth of thiotrophic symbionts over methanotrophic ones. Therefore, the working hypothesis made in the model that the host mussel feeds indifferently on both types of symbionts is incorrect. The model shows that if the mussel does not discriminate its uptake of carbon between both symbionts, then the one with the slowest growth (here the MOX) cannot survive. It is thus probable that there is a selection of the carbon source. For example, an interesting modification of our model would be to make host consumption on either symbiont vary with symbiont activity. Thus, if SOX symbionts are actively growing using available sulphide, MOX growth is reduced due to low methane concentrations, and the mussels would primarily feed on SOX. Another possibility would be to modify the dynamics of the potential competition for space of these symbionts in the mussel gills. For example, this kind of spatial competition has been modelled in (Fung et al., 2011) between coral and algae. The hypothesis made in this model of host feeding indifferently on both types of symbionts was mainly driven by a lack of data on the transfer mechanisms that actually occur. These mechanisms should be further explored before improving the conceptual model.

\subsection{The biology of Bathymodiolus azoricus and its interactions with the fluid}

The modelling approach allowed us to build hypotheses on un-measured carbon flows, from the input of food sources in the system to their uptake by mussels and symbionts and to the loss terms. The modelled environment around the mussels determines the availability of their food. Stable state concentrations of dihydrogen sulphide were close to in situ measurements of concentrations in total dissolved sulphide, although these concentrations tended to be overestimated in the cold samples and underestimated in the warm ones. In the cold part of the gradient, overestimation of dihydrogen sulphide concentrations can be attributed to the absence of abiotic reactions and consumption of dihydrogen sulphide by free-living microorganisms in the model. These two factors have the potential to decrease ambient dihydrogen sulphide concentrations. A biogeochemical model (Perhirin et al., Ifremer, in preparation) is currently being built to predict the evolution of chemical species and primary production along this gradient through dilution, oxidation, transport and chemosynthetic reactions. Coupling this biogeochemical model to the present ecological model will help 
determine the precise input conditions for dihydrogen sulphide, methane and organic carbon concentrations. It will be particularly relevant for the organic carbon source, which we expect to be mainly derived from these free-living chemosynthetic bacteria, as our model lacks the data to spatially constrain this variable. Coupling the biogeochemical model with our model would also affect limiting factors. For example, oxygen was equally limiting for warm and cold samples, but differences may be brought to light if the microbial and chemical uses affect oxygen levels differently in various habitats. Another explanation for the overestimation of dihydrogen sulphide concentrations can be attributed to the model's use of fixation rates measured on large mussels only, whereas smaller individuals usually have higher consumption rates, as reported for coastal mussels (Hamburger et al., 1983; Speakman, 2005; Vahl, 1973; Widdows, 1978) and live in the coldest part of the gradient (Cuvelier et al., 2011a)

In the warm part of the gradient, predictions for dihydrogen sulphide are underestimated compared with the total dissolved sulphide observations. This may be due to the absence of methanotrophy in the model, whereby thiotrophy overcompensated by uptaking too much dihydrogen sulphide, decreasing its surrounding concentrations. Also, the model describes dihydrogen sulphide concentrations, but in situ measurements correspond to concentrations of total dissolved sulphides, which include dihydrogen sulphide as well as other substrates available for SOX. Thiotrophic symbionts in Bathymodiolus species can use several forms of sulphur (e.g. sulphides, thiosulfate, polysulphides in B. septemdierum, Beinart et al., 2015) and are also able to use dihydrogen (Petersen et al., 2011). Although uptake of these other forms has never been shown nor measured for $B$. azoricus, the uptake of dihydrogen has been measured for Bathymodiolus puteoserpentis, a mussel phylogenetically close to $B$. azoricus. However, the low concentrations of hydrogen in Lucky Strike, a basaltic vent field (Charlou et al., 2000) and the apparent low uptake of hydrogen by $B$. puteoserpentis measured in a non-ultramafic vent field (maximum uptake of 0.316 $\mu \mathrm{mol} \mathrm{H}_{2} / \mathrm{g}$ wwgill/h in Lilliput, Petersen et al. 2011) suggest that hydrogen plays a minor role in $B$. azoricus nutrition. Mussel nutrition depends strongly on dihydrogen sulphide concentrations. Given that the measuredconcentrations in the mussel habitat (0 to $40 \mu \mathrm{mol}$ $\mathrm{TdS} / \mathrm{L}$, Sarrazin et al., (2015); 0-50 $\mu \mathrm{mol} \mathrm{CH}_{4}$, Sarradin, pers. comm.) are low compared with concentrations at which maximum uptake rate isreached experimentally (> $200 \mu \mathrm{mol}$ $\mathrm{H}_{2} \mathrm{~S} / \mathrm{L}$, Henry et al., 2008, $300 \mu \mathrm{mol} \mathrm{CH} \mathrm{CH}_{4} / \mathrm{L}$, Kochevar et al., 1992), the maximum dihydrogen sulphide and methane uptake rates are strongly limited by the substrate concentrations. A major improvement of the model includes determining the relationship between the functional dependence of the uptake rates and increasing substrate concentration and taking the size of the mussels into account, as well as the proportion of gill surface occupied by symbionts. Some of these experiments have already been performed on hydrothermal species in pressurized (Beinart et al., 2015) or unpressurized (B. azoricus, (Riou et al., 2010, 2008), used in this model) aquaria and in a relatively exhaustive experiment at atmospheric pressure on cold seep mussels (Kochevar et al., 1992). These experimental results were compared with the modelled uptake rates of $\mathrm{H}_{2} \mathrm{~S}$ and predicted rates (ranging between 4.1 to $6.7 \mu \mathrm{mol} \mathrm{H}_{2} \mathrm{~S} / \mathrm{g} \mathrm{DW} / \mathrm{h}$ ) are twice as high as the maximal uptake rates measured ex situ $\left(3.43 \mu \mathrm{mol} \mathrm{H} \mathrm{H}_{2} \mathrm{~S} / \mathrm{g} \mathrm{DW} / \mathrm{h}\right.$, in (Henry et al., 2008)) on the hydrothermal vent mussel $B$. septemdierum. On the other hand, modelled uptake rates, whenconverted to $\mu \mathrm{mol} \mathrm{H}_{2} \mathrm{~S}$ g wet weight gill/h (ranging from 1.2 to $2.0 \mu \mathrm{mol} \mathrm{H}_{2} \mathrm{~S} / \mathrm{g}$ wet weight gill/h), are approximately three times lower than published results on $B$. septemdierum under pressure $\left(7.4 \mu \mathrm{molH}_{2} \mathrm{~S} / \mathrm{g}\right.$ wet weight gills/h, Beinart et al., 2015). Because the model predictions fall within the range of observed values, our model appears to return biologically realistic results for the dihydrogen sulphide uptake rate. Contrastingly, our 
modelled uptake rates are 10 times lower than those obtained by calibration in a previous model on B. azoricus (Martins et al., 2008). In this previous model, the high uptake rates were needed to compensate high energy losses that this model imposed. Our model benefitted from recent data on deep-sea mussels collected since then, which help improved model constraints.

Given that the model fails to reproduce MOX survival, the only food so urces for $B$. azoricus are bacterial products produced by the oxidation of dihydrogen sulphide and particulate and dissolved organic carbon. The relative contribution of symbiosis $(\sim 74 \%)$ to $B$. azoricus nutrition was consistent with the results of isotopic analyses that report a largely symbiontdependent nutrition (Colaço et al., 2002; De Busserolles et al., 2009; Trask and Van Dover, 1999). Symbiosis may be the main food source for the mussel and filtration of organic carbon would constitute a secondary food source. In the model, this result is probably because assimilation of organic carbon via filtration is less efficient $(A E O C=0.17)$ than via symbiotic production $(A E b a c=0.98)$. Given that the transfer rate to the host is low (TransRate $=0.05 / \mathrm{d}$ ), the symbionts can build up considerable biomass, ultimately occupying almost all the gill area. Very recent proteome analysis of $B$. azoricus (Ponnudurai et al., 2017) seem to reveal a transfer mode of carbon by digestion of the symbionts by the host. Further studies of the rates and modalities of this transfer would bring essential data to improve this model.

Regarding the loss terms in the model, faeces production was low compared with losses through respiration and growth investment. When multiplied by mussel biomass, faeces production scales up to 0.8 to $34 \mathrm{mmol} \mathrm{C} / \mathrm{m}^{2} / \mathrm{d}$, varying similarly in its magnitude as the uptake of organic carbon through filtration. This faecal production is probably mainly composed of non-assimilated organic carbon, which has low assimilation efficiency (AEoc $=0.17$ ). The resulting rate was in the range of values collected by particle traps deployed at the Lucky Strike vent field (52 to $308 \mathrm{mg} / \mathrm{m}^{2} / \mathrm{d}=4.3$ to $25.6 \mathrm{mmol} \mathrm{C} / \mathrm{m}^{2} / \mathrm{d}$ on Sintra edifice, Khripounoff et al., 2008). However, more data are needed, in particular for the quantification of primary production, to understand better the importance of $B$. azoricus as a potential food source (secondary production) for the rest of the ecosystem.

Assimilation of organic carbon is also an interesting parameter to study in the context of deep-sea mining. Extraction activities may potentially form a sediment plume carrying particles over to neighbouring active vent sites (Boschen et al., 2013; Collins et al., 2013). Assimilation efficiency of organic carbon (AEoc) was defined as constant in this model, although its value may vary according to particle concentration and quality (Bayne et al., 1993). The impact of the concentration and quality of particles on the parameter AEoc can be used to assess the effect of particle overload on mussel filtration capacity, because these particles are likely to be mainly mineral. This is particularly interesting because AEoc was one of the most influential parameters in the model, as revealed by the final sensitivity analysis.

Finally, the model showed that assimilated matter is partially respired, while the rest is fixed as biomass. (Khripounoff et al., 2017) reported respiration rates higher for $B$. azoricus than for other deep-sea bivalves. When considering the modelled respiration rates of the mussels and theirsymbionts and converting them to comparable units, they range from 9.7 to $15.3 \mu \mathrm{mol} \mathrm{O} / \mathrm{g}$ dry weight of mussel/h, which is only on average $5 \pm 0.4 \mu \mathrm{mol} \mathrm{O} / 2 / \mathrm{g}$ dry weight of mussel/h more thanthe previously estimated ex situ respiration rates (Martins et al., 2008) and in the range $\left(0 \pm 0.5 \mu \mathrm{mol} \mathrm{O}_{2} / \mathrm{g}\right.$ dry weight of mussel $\left./ \mathrm{h}\right)$ of in situ measured respiration rates (Khripounoff et al., 2017). Although it has not been taken into account in this model, SOX symbionts are also able to use nitrate or nitrite as an electron acceptor instead 
of oxygen (Lee et al., 1999; Nelson and Hagen, 1995). This would allow respiration in less oxygenated environments. Oxygen was not limiting in the samples in this study, but further research on the modalities and on the quantification of this process could allow a better assessment of $B$. azoricus adaptability to oxic/anoxic interfaces.

To conclude, predicted dihydrogen sulphide uptake rates, total respiration rates and relative contribution of symbiosis to the nutrition of $B$. azoricus were consistent with the literature, lending support to the biological realism of the model. The model thus appears to provide likely rate estimates, such as faecal production, which is an important factor to consider when studying the potential importance of $B$. azoricus in the secondary production on the edifice, and its link to the rest of the ecosystem. The model tends to support the hypothesis of carbon transfer to host without digestion of the symbionts, but confirmation requires an improvement of the modelled dynamics of the dual symbiosis. The validity of the model is sufficient for use for simulations.

\subsection{Dynamics of the interactions between Bathymodiolus azoricus and its environment}

Two simulations were conducted, estimating the evolution of a mussel assemblage biomass after wo types of disturbance: partial faunal removal (direct disturbance) and flow interruption of various durations (indirect disturbance). To put these results into perspective, although there were no statistical differences between predicted and observed biomass, the model's predictive power was low for this state variable and dual symbiosis could not be represented. However, the dynamics were relatively reliable, with metabolic rates consistent with the literature (see 4.2).

Simulation of a re-establishing assemblage after partial removal of mussels showed that a stable state is reached in an astonishing time span: only after about 30 to 60 years, depending on the temperature of the surrounding water. This long-time lag is due to the slow metabolic rates, implying a very long-life span for $B$. azoricus, of several decades at least. Spatially, these slow rates, especially in the cold environment, support the hypothesis of mussel migration to warmer habitats to meet energy requirements. Temporally, this simulation suggests that natural or anthropogenic removal has a long-term impact on the ecosystem, because $B$. azoricus, and all the species that depend on it, do not reach their original, stable state before many decades.

The second simulation highlights the dynamics of mussel biomass following an interruption in flow (indirect disturbance). Such an interruption can occur naturally following a seismic event or due to the progressive decrease in substratum porosity but could also result from anthropogenic disturbance.

The biomass of the symbionts responded rapidly, first decreasing as they rapidly reduce the concentrations in dihydrogen sulphide through consumption, then quickly approaching initial values within a few days after the return of the flow. However, they never reached their exact initial state, because they are limited by the slightly smaller biomass (and thus body size and gill surface) of the mussels compared to before the interruption. In our model, symbiont biomass is transferred to the host at a constant rate, which constitutes the only carbon loss of the symbionts, although lysosomal activity appears to increase in $B$. azoricus gills when removed from fluid influence (Detree et al., 2016). Similarly, long-term starvation experiments on the coastal symbiotic lucinid Codakia orbicularis (hosting sulphur-oxidizing endosymbionts) suggest that the survival of the host relies on symbiont digestion (Caro et al., 2009). It is also hypothesized that symbionts can leave the gills when the host is removed 
from the fluid (Kádár et al., 2005). These observations suggest that symbiont (and, consequently, mussel) resilience may be more affected by flow interruption than in the model. Together with the difficulty of the model to reproduce MOX and SOX co-occurrence in the gills, these results emphasize the need to study $B$. azoricus symbiosis in more detail.

Mussel biomass dynamics depends on that of its symbionts. Contrastingly to the symbiont biomass, although the flow was interrupted for 100 to 400 days, the decrease in mussel biomass was relatively low. This suggests that mussels can maintain relatively high biomass after flow interruption, unless they are consumed by other members of the hydrothermal ecosystem or removed by external predators. Bivalves are known to be resistant to food shortages. In fact, coastal bivalves display reduced metabolic rates during starvation periods (Bayne et al., 1993; Widdows, 1973). In addition, the high survival rates (93.5\%) of shallowwater bivalves observed after 60 days of starvation, can be explained by the consumption of their lipid reserves and their eventual switch to a proteinaceous diet (Hong-sheng et al., 2001). Temperature also influences the impact of starvation period. Similarly, (Chase and McMahon, 1995) showed that the zebra mussel, Dreissena polymorpha, displayed $100 \%$ mortality after 166 days of starvation at $25^{\circ} \mathrm{C}$, whereas no mortality was observed at 5 and $15^{\circ} \mathrm{C}$ after 229 days. Metabolic rates in the cold deep sea are known to be lower than in coastal environments (Childress et al., 1990; D'Hondt et al., 2002; Graham et al., 1985). This property was observed in the first simulation, as well as in the second one because the biomass growth rate after the return of flow was higher in the warmer sample than in the colder one. Such low biomass decreases after 100-400 days of flow interruption suggest high resistance (capacity to maintain a stable state after a disturbance), and low growth rates imply low resilience (low capacity to return to the stable state) of mussel biomass after a natural disturbance.

To conclude, simulation results show that direct disturbances such as mussel removal would have a long-term impact on the ecosystem. Indirect disturbances such as flow interruptions also exhibit a long-term impact on mussel biomass but to a lesser extent. Low metabolic rates allow mussel biomass to resist disturbance, and the quick recovery of symbiont biomass upon the return of fluid flow ensures mussel resilience.

\section{Conclusion}

We built a model to better understand the spatial and temporal dynamics of Bathymodiolus azoricus through the study of carbon exchanges between the mussels and their environment and the potential limiting factors that influence their growth. The model significantly improves the previous model related to $B$. azoricus (Martins et al., 2008) by integrating recent published data and explicitly incorporating environmental dynamics. Coupling with an upcoming biogeochemical model will help to fine-tune its predictions and thus improve our understanding of the interactions between the mussels and their ecosystems. The low predicted metabolic rates led to low growth rates, further constrained by a strong impact of temperature on enzymatic activity in the coldest samples. The model highlights the need for a better understanding of the host-symbiont relationship. Quantification of faeces production flows by the model and important biomass suggest that the mussels may represent significant secondary producers for the ecosystem, reinforcing the role of $B$. azoricus as a foundation species. Simulation of mussel biomass during the establishment on new substratum and following a disturbance would indicate that mussel low metabolic rates and 
the rapid dynamics of symbionts allows the mussels to resist flow interruption relatively well, although potential increased consumption of symbiotic carbon by the host might affect symbiont and mussel resilience. The structure of our model, with its three components (environmental conditions-symbionts-foundation species) can be applied to most symbiotic foundation species to better understand their role in the functioning and maintenance of hydrothermal ecosystems.

\section{Acknowledgments}

We are grateful to the crews, ROV Victor 6000 pilots and captains Philippe Guillemet, Thierry Alix and Gilles Ferrand of the French vessel R/V Pourquoi Pas? for their invaluable help during the three cruises during which the data were collected for this model (MOMARETO $2006 \mathrm{http}: / / \mathrm{dx}$. doi.org/10.17600/6030130, MoMARSAT 2014: http://dx.doi.org/10.17600/14000300 and 2015: http://dx.doi.org/10.17600/15000200). We are also grateful to the Dutch/French FRNL network and to the Université Bretagne Loire for their financial support which favoured the collaboration. $\mathrm{BH}$ was supported by the "Laboratoire d'Excellence" LabexMER (ANR-10-LABX-19) and co-funded by a grant from the French government under the "Investissements d'Avenir" expenditure scheme. The project is also part of the EMSO-Acores research programme (http://www.emso-fr.org/) partly funded by an ANR research grant (ANR Lucky Scales ANR-14- CE02-0008-02). This research has also received funding from the European Union Seventh Framework Programme (FP7/2007-2013) under the MIDAS project, grant agreement no. 603418.

We would also like to thank the two researchers that reviewed this study for their benevolent and useful comments.

\section{Appendix}

\subsection{Appendix A}

Initialization of the calculation of consumption flow OCuptake: Calculation of the maximum uptake rate: Consumption rate of organic carbon by mussels was estimated using available fixation rates of particulate and dissolved organic carbon (POC and DOC) from the literature (Riou et al., 2010). Firstly, they were converted to the system units. Secondly, resulting fixation rates were used to estimate a maximum organic carbon fixation rate. Thirdly, this rate was converted to a maximum uptake rate.

Fixation rates of DOC (IncDOC, in $\mu \mathrm{mol} C$ fixed/g dry weight muscle/h, Table 4 ) and POC (IncPOC, in $\mu \mathrm{mol} \mathrm{C}$ fixed/g dry weight muscle/h, Table 4) were measured at concentrations of $\mathrm{CDOC}=302 \times 10^{-6} \mathrm{~mol} \mathrm{DOC} / \mathrm{L}$ and $\mathrm{CPOC}=263 \times 10^{-6} \mathrm{~mol} \mathrm{POC} / \mathrm{L}$ respectively (Riou et al., 2010). These rates were converted from $\mu \mathrm{mol} C$ fixed/g dry weight muscle/h to $\mathrm{mol} C$ fixed/mol $\mathrm{C}$ of mussel/d by multiplying them by the conversion factor $\mathrm{C} 1$ (Table A.1).

A study on Mytilus edulis (Widdows et al., 1979) reported a maximum uptake rate of 200 $\mathrm{mg} / \mathrm{L}$ of particles containing a maximum of $50 \%$ organic carbon, which is equivalent to $\mathrm{CmaxOC}=8 \mathrm{mmol} 707 \mathrm{OC} / \mathrm{L}$. Our model assumes that the maximum fixation rate of dissolved organic carbon occurs at the same concentration and assumes a linear uptake rate below this concentration. Fixation rates of $\mathrm{POC}$ and $\mathrm{DOC}$ at $\mathrm{CPOC}$ and $\mathrm{CDOC}$ respectively were converted to maximum fixation rates of $\mathrm{POC}$ and of $\mathrm{DOC}$ at $\mathrm{CmaxOC}=8 \times 10^{-3} \mathrm{~mol}$ $\mathrm{OC} / \mathrm{L}$, using a cross product and added as MaxfixationOC (Eq. 1)

$$
\begin{aligned}
\text { MaxfixationOC }(\mathrm{mol} \mathrm{OC} / \mathrm{mol} C \text { of mussel } / \mathrm{d}) & \\
= & \frac{\operatorname{IncPOC} \times C 1 \times \mathrm{CmaxOC}}{C P O C}+\frac{\operatorname{IncDOC} \times C 1 \times C \max O C}{C D O C}
\end{aligned}
$$


Table A.1: Names, values, definitions and units of data taken from the literature (Riou etal.,2008, 2010) and conversion factors used.

\begin{tabular}{|c|c|c|c|}
\hline Name & Value & Definition & Unit \\
\hline CDOC & $302 \times 10^{-6}$ & $\begin{array}{l}\text { Experimental concentration of dissolved } \\
\text { organic carbon }\end{array}$ & $\mathrm{mol} \mathrm{DOC/L}$ \\
\hline CPOC & $263 \times 10^{-6}$ & $\begin{array}{l}\text { Experimental concentration of particulate } \\
\text { organic carbon }\end{array}$ & $\mathrm{mol} \mathrm{POC/L}$ \\
\hline CM & $30 \times 10^{-6}$ & Experimental concentration of methane & $\mathrm{mol} \mathrm{CH}_{4} / \mathrm{L}$ \\
\hline CS & $6 \times 10^{-6}$ & $\begin{array}{l}\text { Experimental concentration of hydrogen } \\
\text { sulphide }\end{array}$ & $\mathrm{mol} \mathrm{H} \mathrm{H}_{2} \mathrm{~S} / \mathrm{L}$ \\
\hline surfM & 5.4 & $\begin{array}{l}\text { Gill surface occupied by methanotrophic } \\
\text { symbionts, ratio of fresh to experimental } \\
\text { mussels }\end{array}$ & No unit \\
\hline surfS & 3.3 & $\begin{array}{l}\text { Gill surface occupied by thiotrophic symbionts, } \\
\text { ratio of fresh to experimental mussels }\end{array}$ & No unit \\
\hline propM & 39 & $\begin{array}{l}\text { Relative proportion of methanotrophic } \\
\text { symbionts }\end{array}$ & $\%$ \\
\hline propS & 96 & Relative proportion of thiotrophic sympbionts & $\%$ \\
\hline sizeM & 62.2 & $\begin{array}{l}\text { Shell length of mussels incubated with } \\
\text { methane }\end{array}$ & $\mathrm{mm}$ \\
\hline sizes & 65.8 & $\begin{array}{l}\text { Shell length of mussels incubated with } \\
\text { hydrogen sulphide }\end{array}$ & $\mathrm{mm}$ \\
\hline C1 & $\begin{array}{l}\text { MuscDW } \times 10^{-6} \times \\
24 \times \text { Mol2dw }\end{array}$ & Conversion for organic carbon fixation rates & $\begin{array}{l}\text { (mol C/mol C of mussel/d) } \\
/(\mu \mathrm{mol} \mathrm{C/g} \mathrm{DW} \mathrm{muscle/h)}\end{array}$ \\
\hline C2 & $\begin{array}{l}\text { GillDWx } 10^{-6} \times 24 \times \\
\text { Mol2dw }\end{array}$ & $\begin{array}{l}\text { Conversion for methane and hydrogen } \\
\text { sulphide fixation rates }\end{array}$ & $\begin{array}{l}\text { (mol C/mol C of mussel/d) } \\
/(\mu \mathrm{mol} \mathrm{C/g} \mathrm{DW} \mathrm{gill/h)}\end{array}$ \\
\hline
\end{tabular}

This fixation rate was converted to uptake rates by dividing them (Eq. 2) by the assimilation efficiency of organic carbon (AEoc, Table 4) and the ratio of fixed to respired carbon (net growth efficiency, NGE, Table 4):

$$
\text { MaxUptOC }(\text { mol OC } / \text { mol C of mussel } / d)=\frac{\text { MaxincorporationOC }}{N G E \times A E O C}
$$

\subsection{Appendix B}

Initialization of the calculation of consumption flow $\mathbf{M}_{\text {uptake: }}$ Calculation of the maximum uptake rate: Fixation rates of carbon of $\mathrm{IncM}=0.23 \mu \mathrm{mol} \mathrm{C}$ fixed $/ \mathrm{g}$ dry weight gills/h were measured by (Riou et al., 2008) in gills of mussels exposed to $\mathrm{CM}=30 \times 10^{-6} \mathrm{~mol} \mathrm{CH}_{4} / \mathrm{L}$ (Table A.1). They needed to be converted to $\mathrm{mol} \mathrm{C}$ fixed $/ \mathrm{mol} \mathrm{C}$ of MOX/d so that fixation follows a pattern that depends on symbiont biomass: the higher the biomass of MOX, the higher the fixation of carbon when exposed to methane and vice versa. This is done in four steps:

Firstly, the fixation rate was converted from $\mu \mathrm{mol} C$ fixed/g dry weight gills $/ \mathrm{h}$ to $\mathrm{mol} \mathrm{C}$ fixed/mol $\mathrm{C}$ of mussel/d by multiplying the measured fixation, IncM, by the conversion factor C2 (Table A.1).

Secondly, it was converted to mol C fixed/individual/d by inferring the weight in moles of the mussel using its length. Mussels in Riou's experiment had a mean length of sizeM=62.2 $\mathrm{mm}$ (Table A.1), 726 so their weight was approximately W.exp $(\mathrm{mol} \mathrm{C})=$ MusselDW 
$($ sizeM $) / M o l 2 d w$, giving an individual fixation rate IncM.Ind $(\mathrm{mol} \mathrm{C} /$ individual $/ \mathrm{d})=\operatorname{IncM} \times \mathrm{C} 2 \times$ W.exp.

Thirdly, it was possible to estimate the biomass of MOX that allowed this fixation, i.e. the biomass of MOX present in the gills of the incubated mussel. The maximum number of symbionts in the gills of a mussel of $62.2 \mathrm{~mm}$ can be estimated using (Duperron et al., 2016) size-to-symbiont number relationship. This number can be converted to biomass by multiplying it by the weight in mol $\mathrm{C}$ of one MOX (Table 1). (Riou et al., 2008) observed that symbionts of mussels kept under this treatment 733 covered a surface that is approximately surfM=5.4 times less than that in freshly collected mussels (Table A.1). In addition, propMOX $=39 \%$ of the observed symbionts were MOX (Table A.1). Thus, the MOX biomass (BiomMOX in $\mathrm{mol} \mathrm{C}$ ) in the incubated individuals can be estimated:

BiomMox $(\operatorname{mol} C$ MOX $)=(\operatorname{Nmax}($ sizeM $) \times$ MolMOX/surfM $) \times$ propMOX

Fourth, the fixation rate can be converted from mol C/individual/ $\mathrm{d}$ to $\mathrm{mol} \mathrm{C}$ fixed $/ \mathrm{mol} \mathrm{C}$ of MOX/d by dividing individual fixation by the estimation of the MOX biomass: IncM.MOX (mol C fixed $/ \mathrm{mol} \mathrm{C}$ of $\mathrm{MOX} / \mathrm{d}$ ) $=$ IncM.Ind/BiomMox.

This fixation rate, however, is probably not the maximal one. (Kochevar et al., 1992) have shown that the fixation of methane is linear up to $\mathrm{CmaxM}=300 \mu \mathrm{mol} \mathrm{CH} \mathrm{CH}_{4} / \mathrm{L}$, where it reaches its maximum. Considering this, the maximum fixation rate MaxFixationM can be estimated through the cross product using the converted fixation (IncM.MOX) at $\mathrm{CM}=30 \mu \mathrm{mol} \mathrm{CH} / \mathrm{L}$ and the concentration of maximum fixation (Eq. 3):

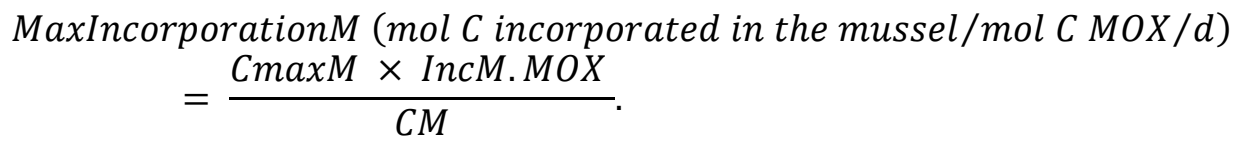

Our model assumes that uptake of methane is linear (Kochevar et al., 1992) with maximum uptake rate occurring at a similar concentration as maximum fixation, $\mathrm{CmaxM}=300 \mu \mathrm{mol}$ $\mathrm{CH}_{4} / \mathrm{L}$ (Kochevar et al., 1992). The obtained fixation rate can be converted to a maximum uptake rate (MaxUptM) by multiplying it by a constant uptM $>1$ (in $\mathrm{mol} \mathrm{CH}_{4}$ uptaken by the $\mathrm{MOX} / \mathrm{mol} \mathrm{C}$ fixed by the mussel, Table 4) (Eq.4):

MaxUptM $\left(\right.$ mol CH$_{4}$ uptaken $m o l$ C MOX/d) $=$ MaxFixationM $\times$ uptM

Eq.4

\subsection{Appendix C}

Initialization of the calculation of consumption flow $\boldsymbol{S}_{\text {uptake: }}$ Sulphide uptake flow is calculated exactly as methane uptake, differing only by the available data. Riou et al. (2008) measured IncS $=0.37 \mu \mathrm{mol} C$ fixed $/ \mathrm{g}$ dry weight gills $/ \mathrm{h}$ in mussels exposed to $\mathbf{C S}=6 \mu \mathrm{mol}$ $\mathrm{H}_{2} \mathrm{~S} / \mathrm{L}$. Mussels were on average sizeS $=65.8 \mathrm{~mm}$ (Table A.1) and had propSOX 96\% of SOX symbionts on a surface surfS 3.3 times smaller than in fresh mussels. According to Henry et al. (2008), maximal uptake rates occurred in Bathymodiolus septemdierum, a Pacific hydrothermal mussel, at $\mathrm{CmaxS}=200 \mu \mathrm{mol} \mathrm{H}_{2} \mathrm{~S} / \mathrm{L}$ (Table 4). 


\section{References}

Anestis, A., Lazou, A., Pörtner, H.O., Michaelidis, B., 2007. Behavioral, metabolic, and molecular stress responses of marine bivalve Mytilus galloprovincialis during longterm acclimation at increasing ambient temperature. Am. J. Physiol. - Regul. Integr. Comp. Physiol. 293, R911-R921. https://doi.org/10.1152/ajpregu.00124.2007

Barber, B.J., Blake, N.J., 1985. Substrate catabolism related to reproduction in the bay scallop Argopecten irradians concentricus, as determined by $\mathrm{O} / \mathrm{N}$ and $\mathrm{RQ}$ physiological indexes. Mar. Biol. 87, 13-18. https://doi.org/10.1007/BF00397001

Barreyre, T., Escartín, J., Sohn, R.A., Cannat, M., Ballu, V., Crawford, W.C., 2014. Temporal variability and tidal modulation of hydrothermal exit-fluid temperatures at the Lucky Strike deep-sea vent field, Mid-Atlantic Ridge. J. Geophys. Res. Solid Earth 119, 2013JB010478. https://doi.org/10.1002/2013JB010478

Bayne, B.L., Iglesias, J.I.P., Hawkins, A.J.S., Navarro, E., Heral, M., Deslous-Paoli, J.M., 1993. Feeding behaviour of the mussel, Mytilus edulis: responses to variations in quantity and organic content of the seston. J. Mar. Biol. Assoc. U. K. 73, 813-829. https://doi.org/10.1017/S0025315400034743

Beinart, R.A., Gartman, A., Sanders, J.G., Luther, G.W., Girguis, P.R., 2015. The uptake and excretion of partially oxidized sulfur expands the repertoire of energy resources metabolized by hydrothermal vent symbioses. Proc R Soc B 282, 20142811. https://doi.org/10.1098/rspb.2014.2811

Bergquist, D.C., Eckner, J.T., Urcuyo, I.A., Cordes, E.E., Hourdez, S., Macko, S.A., Fisher, C.R., 2007. Using stable isotopes and quantitative community characteristics to determine a local hydrothermal vent food web. Mar. Ecol. Prog. Ser. 330, 49-65.

Blanchard, G., Guarini, J.-M., Richard, P., Gros, P., Mornet, F., 1996. Quantifying the shortterm temperature effect on light-saturated photosynthesis of intertidal microphytobenthos. Mar. Ecol. Prog. Ser. 134, 309-313. https://doi.org/10.3354/meps134309

Boschen, R.E., Rowden, A.A., Clark, M.R., Gardner, J.P.A., 2013. Mining of deep-sea seafloor massive sulfides: A review of the deposits, their benthic communities, impacts from mining, regulatory frameworks and management strategies. Ocean Coast. Manag. 84, 54-67. https://doi.org/10.1016/j.ocecoaman.2013.07.005

Caro, A., Got, P., Bouvy, M., Troussellier, M., Gros, O., 2009. Effects of Long-Term Starvation on a Host Bivalve (Codakia orbicularis, Lucinidae) and Its Symbiont Population. Appl. Environ. Microbiol. 75, 3304-3313. https://doi.org/10.1128/AEM.02659-08

Cavanaugh, C.M., Gardiner, S.L., Jones, M.L., Jannasch, H.W., Waterbury, J.B., 1981. Prokaryotic Cells in the Hydrothermal Vent Tube Worm Riftia pachyptila Jones: Possible Chemoautotrophic Symbionts. Science 213, 340-342. https://doi.org/10.1126/science.213.4505.340

Charlou, J.L., Donval, J.P., Douville, E., Jean-Baptiste, P., Radford-Knoery, J., Fouquet, Y., Dapoigny, A., Stievenard, M., 2000. Compared geochemical signatures and the evolution of Menez Gwen $\left(37^{\circ} 50^{\prime} \mathrm{N}\right)$ and Lucky Strike $\left(37^{\circ} 17^{\prime} \mathrm{N}\right)$ hydrothermal fluids, south of the Azores Triple Junction on the Mid-Atlantic Ridge. Chem. Geol. 171, 4975. https://doi.org/10.1016/S0009-2541(00)00244-8

Chase, R., McMahon, R.F., 1995. Effects of Starvation at Different Temperatures on Dry Tissue and Dry Shell Weights in the Zebra Mussel, Dreissena polymorpha (Pallas).

Childress, J.J., Cowles, D.L., Favuzzi, J.A., Mickel, T.J., 1990. Metabolic rates of benthic deep-sea decapod crustaceans decline with increasing depth primarily due to the decline in temperature. Deep Sea Res. Part Oceanogr. Res. Pap. 37, 929-949. https://doi.org/10.1016/0198-0149(90)90104-4

Clarke, A., Fraser, K.P.P., 2004. Why does metabolism scale with temperature? Funct. Ecol. 18, 243-251. https://doi.org/10.1111/j.0269-8463.2004.00841.x

Colaço, A., Dehairs, F., Desbruyères, D., 2002. Nutritional relations of deep-sea hydrothermal fields at the Mid-Atlantic Ridge: a stable isotope approach. Deep Sea 
Res. Part Oceanogr. Res. Pap. 49, 395-412. https://doi.org/10.1016/S09670637(01)00060-7

Collins, P.C., Croot, P., Carlsson, J., Colaço, A., Grehan, A., Hyeong, K., Kennedy, R., Mohn, C., Smith, S., Yamamoto, H., Rowden, A., 2013. A primer for the Environmental Impact Assessment of mining at seafloor massive sulfide deposits. Mar. Policy 42, 198-209. https://doi.org/10.1016/j.marpol.2013.01.020

Comtet, T., Desbruyeres, D., 1998. Population structure and recruitment in mytilid bivalves from the Lucky Strike and Menez Gwen. Mar. Ecol. Prog. Ser. 163, 165-177.

Conway, N.M., Kennicutt, M.C., Van Dover, C.L., 1994. Stable isotopes in the study of marine chemosynthetic-based ecosystems. Stable Isot. Ecol. Environ. Sci. Blackwell 158-186.

Cuvelier, D., Sarradin, P.-M., Sarrazin, J., Colaço, A., Copley, J.T., Desbruyères, D., Glover, A.G., Santos, R.S., Tyler, P.A., 2011a. Hydrothermal faunal assemblages and habitat characterisation at the Eiffel Tower edifice (Lucky Strike, Mid-Atlantic Ridge). Mar. Ecol. 32, 243-255.

Cuvelier, D., Sarrazin, J., Colaço, A., Copley, J., Desbruyères, D., Glover, A.G., Tyler, P., Serrão Santos, R., 2009. Distribution and spatial variation of hydrothermal faunal assemblages at Lucky Strike (Mid-Atlantic Ridge) revealed by high-resolution video image analysis. Deep Sea Res. Part Oceanogr. Res. Pap. 56, 2026-2040. https://doi.org/10.1016/j.dsr.2009.06.006

Cuvelier, D., Sarrazin, J., Colaço, A., Copley, J.T., Glover, A.G., Tyler, P.A., Santos, R.S., Desbruyères, D., 2011b. Community dynamics over 14 years at the Eiffel Tower hydrothermal edifice on the Mid-Atlantic Ridge. Limnol. Oceanogr. 56, 1624-1640.

Dayton, P.K., 1972. Toward an understanding of community resilience and the potential effects of enrichments to the benthos at McMurdo Sound, Antarctica, in: Proceedings of the Colloquium on Conservation Problems in Antarctica. Allen Press, Lawrence, Kansas, USA. pp. 81-95.

De Busserolles, F., Sarrazin, J., Gauthier, O., Gélinas, Y., Fabri, M.C., Sarradin, P.M., Desbruyères, D., 2009. Are spatial variations in the diets of hydrothermal fauna linked to local environmental conditions? Deep Sea Res. Part II Top. Stud. Oceanogr., Marine Benthic Ecology and Biodiversity: A Compilation of Recent Advances in Honor of J. Frederick Grassle 56, 1649-1664. https://doi.org/10.1016/j.dsr2.2009.05.011

Desbruyères, D., Almeida, A., Biscoito, M., Comtet, T., Khripounoff, A., Bris, N.L., Sarradin, P.M., Segonzac, M., 2000. A review of the distribution of hydrothermal vent communities along the northern Mid-Atlantic Ridge: dispersal vs. environmental controls, in: Jones, M.B., Azevedo, J.M.N., Neto, A.I., Costa, A.C., Martins, A.M.F. (Eds.), Island, Ocean and Deep-Sea Biology, Developments in Hydrobiology. Springer Netherlands, pp. 201-216. https://doi.org/10.1007/978-94-017-1982-7_19

Detree, C., Chabenat, A., Lallier, F.H., Satoh, N., Shoguchi, E., Tanguy, A., Mary, J., $2 \overline{0} 16$. Multiple I-Type Lysozymes in the Hydrothermal Vent Mussel Bathymodiolus azoricus and Their Role in Symbiotic Plasticity. PLOS ONE 11, e0148988. https://doi.org/10.1371/journal.pone.0148988

D'Hondt, S., Rutherford, S., Spivack, A.J., 2002. Metabolic Activity of Subsurface Life in Deep-Sea Sediments. Science 295, 2067-2070. https://doi.org/10.1126/science.1064878

Distel, D.L., Lee, H.K., Cavanaugh, C.M., 1995. Intracellular coexistence of methano- and thioautotrophic bacteria in a hydrothermal vent mussel. Proc. Natl. Acad. Sci. 92, 9598-9602.

Dolmer, P., 2000. Algal concentration profiles above mussel beds. J. Sea Res. 43, 113-119. https://doi.org/10.1016/S1385-1101(00)00005-8

Duperron, S., Bergin, C., Zielinski, F., Blazejak, A., Pernthaler, A., McKiness, Z.P., DeChaine, E., Cavanaugh, C.M., Dubilier, N., 2006. A dual symbiosis shared by two mussel species, Bathymodiolus azoricus and Bathymodiolus puteoserpentis (Bivalvia: Mytilidae), from hydrothermal vents along the northern Mid-Atlantic Ridge. Environ. Microbiol. 8, 1441-1447. https://doi.org/10.1111/j.1462-2920.2006.01038.x 
Duperron, S., Quiles, A., Szafranski, K.M., Léger, N., Shillito, B., 2016. Estimating Symbiont Abundances and Gill Surface Areas in Specimens of the Hydrothermal Vent Mussel Bathymodiolus puteoserpentis Maintained in Pressure Vessels. Front. Mar. Sci. 3. https://doi.org/10.3389/fmars.2016.00016

Edwards, W.J., Rehmann, C.R., McDonald, E., Culver, D.A., 2005. The impact of a benthic filter feeder: limitations imposed by physical transport of algae to the benthos. Can. J. Fish. Aquat. Sci. 62, 205-214.

Felbeck, H., 1981. Chemoautotrophic Potential of the Hydrothermal Vent Tube Worm, Riftia pachyptila Jones (Vestimentifera). Science 213, 336-338. https://doi.org/10.1126/science.213.4505.336

Fennel, W., Neumann, T., 2014. Introduction to the Modelling of Marine Ecosystems. Elsevier.

Fiala-Médioni, A., McKiness, Z., Dando, P., Boulegue, J., Mariotti, A., Alayse-Danet, A., Robinson, J., Cavanaugh, C., 2002. Ultrastructural, biochemical, and immunological characterization of two populations of the mytilid mussel Bathymodiolus azoricus from the Mid-Atlantic Ridge: evidence for a dual symbiosis. Mar. Biol. 141, 1035-1043. https://doi.org/10.1007/s00227-002-0903-9

Fisher, C.R., Childress, J.J., 1986. Translocation of fixed carbon from symbiotic bacteria to host tissues in the gutless bivalve Solemya reidi. Mar. Biol. 93, 59-68. https://doi.org/10.1007/BF00428655

Fisher, C.R., Childress, J.J., Minnich, E., 1989. Autotrophic Carbon Fixation by the Chemoautotrophic Symbionts of Riftia pachyptila. Biol. Bull. 177, 372-385. https://doi.org/10.2307/1541597

Frechette, M., Aitken, A.E., Page, L., 1992. Interdependence of food and space limitation of a benthic suspension feeder: Consequences for self-thinning relationships. Mar. Ecol. Prog. Ser. Oldendorf 83, 55-62.

Frechette, M., Butman, C.A., Geyer, W.R., Bah, W.T.A., 1989. The importance of boundarylayer flows in supplying phytoplankton to the benthic suspension feeder, Mytilus edulis L. Limnol Ocean.

Frechette, M., Lefaivre, D., 1990. Discriminating between food and space limitation in benthic suspension feeders using self-thinning relationships. Mar Ecol Prog Ser 65, 15-23.

Fung, T., Seymour, R.M., Johnson, C.R., 2011. Alternative stable states and phase shifts in coral reefs under anthropogenic stress. Ecology 92, 967-982. https://doi.org/10.1890/10-0378.1

Girguis, P.R., Childress, J.J., 2006. Metabolite uptake, stoichiometry and chemoautotrophic function of the hydrothermal vent tubeworm Riftia pachyptila: responses to environmental variations in substrate concentrations and temperature. J. Exp. Biol. 209, 3516-3528. https://doi.org/10.1242/jeb.02404

Girguis, P.R., Childress, J.J., Freytag, J.K., Klose, K., Stuber, R., 2002. Effects of metabolite uptake on proton-equivalent elimination by two species of deep-sea vestimentiferan tubeworm, Riftia pachyptila and Lamellibrachia cf luymesi: proton elimination is a necessary adaptation to sulfide-oxidizing chemoautotrophic symbionts. J. Exp. Biol. 205, 3055-3066.

Gollner, S., Fontaneto, D., Arbizu, P.M., 2010. Molecular taxonomy confirms morphological classification of deep-sea hydrothermal vent copepods (Dirivultidae) and suggests broad physiological tolerance of species and frequent dispersal along ridges. Mar. Biol. 158, 221-231. https://doi.org/10.1007/s00227-010-1553-y

Govenar, B., Fisher, C.R., 2007. Experimental evidence of habitat provision by aggregations of Riftia pachyptila at hydrothermal vents on the East Pacific Rise. Mar. Ecol. 28, 314. https://doi.org/10.1111/j.1439-0485.2007.00148.x

Govenar, B., Le Bris, N., Gollner, S., Glanville, J., Aperghis, A., Hourdez, S., Fisher, C., 2005. Epifaunal community structure associated with Riftia pachyptila aggregations in chemically different hydrothermal vent habitats. Mar. Ecol. Prog. Ser. 305, 67-77. https://doi.org/10.3354/meps305067 
Graham, M.S., Haedrich, R.L., Fletcher, G.L., 1985. Hematology of three deep-sea fishes: a reflection of low metabolic rates. Comp. Biochem. Physiol. A 80, 79-84. https://doi.org/10.1016/0300-9629(85)90682-6

Guiñez, R., Castilla, J.C., Sterner, A.E.R.W., 1999. A Tridimensional Self-Thinning Model for Multilayered Intertidal Mussels. Am. Nat. 154, 341-357. https://doi.org/10.1086/303234

Halary, S., Riou, V., Gaill, F., Boudier, T., Duperron, S., 2008. 3D FISH for the quantification of methane- and sulphur-oxidizing endosymbionts in bacteriocytes of the hydrothermal vent mussel Bathymodiolus azoricus. ISME J. 2, 284-292. https://doi.org/10.1038/ismej.2008.3

Hamburger, K., Møhlenberg, F., Randløv, A., Riisgård, H.U., 1983. Size, oxygen consumption and growth in the mussel Mytilus edulis. Mar. Biol. 75, 303-306. https://doi.org/10.1007/BF00406016

Heijnen, J.J., Van Dijken, J.P., 1992. In search of a thermodynamic description of biomass yields for the chemotrophic growth of microorganisms. Biotechnol. Bioeng. 39, 833858. https://doi.org/10.1002/bit.260390806

Henry, M.S., Childress, J.J., Figueroa, D., 2008. Metabolic rates and thermal tolerances of chemoautotrophic symbioses from Lau Basin hydrothermal vents and their implications for species distributions. Deep Sea Res. Part Oceanogr. Res. Pap. 55, 679-695. https://doi.org/10.1016/j.dsr.2008.02.001

Hong-sheng, Y., Jian, W., Yi, Z., Ping, W., Yi-chao, H., Fu-sui, Z., 2001. Impact of starvation on survival, meat condition and metabolism ofChlamys farreri. Chin. J. Oceanol. Limnol. 19, 51-56. https://doi.org/10.1007/BF02842789

Husson, B., Sarradin, P.-M., Zeppilli, D., Sarrazin, J., 2017. Picturing thermal niches and biomass of hydrothermal vent species. Deep Sea Res. Part II Top. Stud. Oceanogr., Advances in deep-sea biology: biodiversity, ecosystem functioning and conservation 137, 6-25. https://doi.org/10.1016/j.dsr2.2016.05.028

Jannasch, H.W., 1995. Microbial Interactions with Hydrothermal Fluids, in: Humphris, S.E., Zierenberg, R.A., Mullineaux, L.S., Thomson, R.E. (Eds.), Seafloor Hydrothermal Systems: Physical, Chemical, Biological, and Geological Interactions. American Geophysical Union, pp. 273-296.

Jannasch, H.W., Wirsen, C.O., 1979. Chemosynthetic Primary Production at East Pacific Sea Floor Spreading Centers. BioScience 29, 592-598. https://doi.org/10.2307/1307765

Johnson, H.P., Tunnicliffe, V., 1985. Time-series measurements of hydrothermal activity on northern Juan De Fuca Ridge. Geophys. Res. Lett. 12, 685-688. https://doi.org/10.1029/GL012i010p00685

Johnson, K.S., Childress, J.J., Beehler, C.L., 1988a. Short-term temperature variability in the Rose Garden hydrothermal vent field: an unstable deep-sea environment. Deep Sea Res. Part Oceanogr. Res. Pap. 35, 1711-1721. https://doi.org/10.1016/01980149(88)90045-3

Johnson, K.S., Childress, J.J., Hessler, R.R., Sakamoto-Arnold, C.M., Beehler, C.L., 1988b. Chemical and biological interactions in the Rose Garden hydrothermal vent field, Galapagos spreading center. Deep Sea Res. Part Oceanogr. Res. Pap. 35, 17231744. https://doi.org/10.1016/0198-0149(88)90046-5

Kádár, E., Bettencourt, R., Costa, V., Santos, R.S., Lobo-da-Cunha, A., Dando, P., 2005. Experimentally induced endosymbiont loss and re-acquirement in the hydrothermal vent bivalve Bathymodiolus azoricus. J. Exp. Mar. Biol. Ecol. 318, 99-110. https://doi.org/10.1016/j.jembe.2004.12.025

Khripounoff, A., Caprais, J.C., Decker, C., Le Bruchec, J., Noel, P., Husson, B., 2017. Respiration of bivalves from three different deep-sea areas: Cold seeps, hydrothermal vents and organic carbon-rich sediments. Deep Sea Res. Part II Top. Stud. Oceanogr. https://doi.org/10.1016/j.dsr2.2016.05.023

Khripounoff, A., Vangriesheim, A., Crassous, P., Segonzac, M., Lafon, V., Warén, A., 2008. Temporal variation of currents, particulate flux and organism supply at two deep-sea 
hydrothermal fields of the Azores Triple Junction. Deep Sea Res. Part Oceanogr.

Res. Pap. 55, 532-551. https://doi.org/10.1016/j.dsr.2008.01.001

Kiørboe, T., Møhlenberg, F., Nøhr, O., 1981. Effect of suspended bottom material on growth and energetics in Mytilus edulis. Mar. Biol. 61, 283-288.

https://doi.org/10.1007/BF00401567

Kochevar, R.E., Childress, J.J., Fisher, C.R., Minnich, E., 1992. The methane mussel: roles of symbiont and host in the metabolic utilization of methane. Mar. Biol. 112, 389-401. https://doi.org/10.1007/BF00356284

Langmuir, C., Charlou, J.-L., Colodner, D., Costa, I., Desbruyeres, D., Desonie, D., Emerson, T., Fornari, D., Fouquet, Y., Humphris, S., Fiala-Medioni, A., Saldanha, L., SoursPage, R., Thatcher, M., Tivey, M.K., Van Dover, C., Von Damm, K., Wiese, K., Wilson, C., 1993. Lucky Strike - A newly discovered hydrothermal site on the Azores platform. Ridge Events 4, 3-5.

Le Bris, N., Duperron, S., 2010. Chemosynthetic communities and biogeochemical energy pathways along the Mid-Atlantic Ridge: The case of Bathymodiolus Azoricus, in: Rona, P.A., Devey, C.W., Dyment, J., Murton, B.J. (Eds.), Diversity Of Hydrothermal Systems On Slow Spreading Ocean Ridges. American Geophysical Union, pp. 409429.

Lee, R.W., Robinson, J.J., Cavanaugh, C.M., 1999. Pathways of inorganic nitrogen assimilation in chemoautotrophic bacteria-marine invertebrate symbioses: expression of host and symbiont glutamine synthetase. J. Exp. Biol. 202, 289-300.

Léveillé, R.J., Levesque, C., Juniper, S.K., 2005. Biotic Interactions and Feedback Processes in Deep-Sea Hydrothermal Vent Ecosystems, in: Kristensen, E., Haese, R.R., Kostka, J.E. (Eds.), Interactions Between Macro- and Microorganisms in Marine Sediments. American Geophysical Union, pp. 299-321.

Luther, G.W., Rozan, T.F., Taillefert, M., Nuzzio, D.B., Di Meo, C., Shank, T.M., Lutz, R.A., Cary, S.C., 2001. Chemical speciation drives hydrothermal vent ecology. Nature 410, 813-816. https://doi.org/10.1038/35071069

Mahaut, M.-L., Sibuet, M., Shirayama, Y., 1995. Weight-dependent respiration rates in deepsea organisms. Deep Sea Res. Part Oceanogr. Res. Pap. 42, 1575-1582. https://doi.org/10.1016/0967-0637(95)00070-M

Mallet, A.L., Carver, C.E.A., Coffen, S.S., Freeman, K.R., 1987. Mortality Variations in Natural Populations of the Blue Mussel, Mytilus edulis. Can. J. Fish. Aquat. Sci. 44, 1589-1594. https://doi.org/10.1139/f87-192

Marsh, L., Copley, J.T., Huvenne, V.A.I., Linse, K., Reid, W.D.K., Rogers, A.D., Sweeting, C.J., Tyler, P.A., 2012. Microdistribution of Faunal Assemblages at Deep-Sea Hydrothermal Vents in the Southern Ocean. PLoS ONE 7, e48348. https://doi.org/10.1371/journal.pone.0048348

Martins, Irene, Colaço, A., Dando, P.R., Martins, Inês, Desbruyères, D., Sarradin, P.-M., Marques, J.C., Serrão-Santos, R., 2008. Size-dependent variations on the nutritional pathway of Bathymodiolus azoricus demonstrated by a C-flux model. Ecol. Model. 217, 59-71. https://doi.org/10.1016/j.ecolmodel.2008.05.008

Nelson, D.C., Hagen, K.D., 1995. Physiology and Biochemistry of Symbiotic and Free-Living Chemoautotrophic Sulfur Bacteria. Integr. Comp. Biol. 35, 91-101. https://doi.org/10.1093/icb/35.2.91

Newell, R.C., 1969. Effect of Fluctuations in Temperature on the Metabolism of Intertidal Invertebrates. Am. Zool. 9, 293-307. https://doi.org/10.1093/icb/9.2.293

Page, H.M., Fiala-Medioni, A., Fisher, C.R., Childress, J.J., 1991. Experimental evidence for filter-feeding by the hydrothermal vent mussel, Bathymodiolus thermophilus. Deep Sea Res. Part Oceanogr. Res. Pap. 38, 1455-1461. https://doi.org/10.1016/01980149(91)90084-S

Petersen, J.M., Zielinski, F.U., Pape, T., Seifert, R., Moraru, C., Amann, R., Hourdez, S., Girguis, P.R., Wankel, S.D., Barbe, V., Pelletier, E., Fink, D., Borowski, C., Bach, W., Dubilier, N., 2011. Hydrogen is an energy source for hydrothermal vent symbioses. Nature 476, 176-180. https://doi.org/10.1038/nature10325 
Podowski, E., Ma, S., Luther, G., Wardrop, D., Fisher, C., 2010. Biotic and abiotic factors affecting distributions of megafauna in diffuse flow on andesite and basalt along the Eastern Lau Spreading Center, Tonga. Mar. Ecol. Prog. Ser. 418, 25-45. https://doi.org/10.3354/meps08797

Podowski, E.L., Moore, T.S., Zelnio, K.A., Luther III, G.W., Fisher, C.R., 2009. Distribution of diffuse flow megafauna in two sites on the Eastern Lau Spreading Center, Tonga. Deep Sea Res. Part Oceanogr. Res. Pap. 56, 2041-2056. https://doi.org/10.1016/j.dsr.2009.07.002

Ponnudurai, R., Kleiner, M., Sayavedra, L., Petersen, J.M., Moche, M., Otto, A., Becher, D., Takeuchi, T., Satoh, N., Dubilier, N., Schweder, T., Markert, S., 2017. Metabolic and physiological interdependencies in the Bathymodiolus azoricus symbiosis. ISME J. 11, 463-477. https://doi.org/10.1038/ismej.2016.124

Posch, T., LofererKrbacher, M., Gao, G., Alfreider, A., Pernthaler, J., Psenner, R., 2001. Precision of bacterioplankton biomass determination: a comparison of two fluorescent dyes, and of allometric and linear volume-to-carbon conversion factors. Aquat. Microb. Ecol. 25, 55-63. https://doi.org/10.3354/ame025055

Powell, M.A., Somero, G.N., 1986. Adaptations to Sulfide by Hydrothermal Vent Animals: Sites and Mechanisms of Detoxification and Metabolism. Biol. Bull. 171, 274-290.

Powell, M.A., Somero, G.N., 1985. Sulfide oxidation occurs in the animal tissue of the gutless clam, solemya reidi. Biol. Bull. 169, 164-181. https://doi.org/10.2307/1541396

$\mathrm{R}$ Core Team, 2015. R: A language and environment for statistical computing. R Foundation for Statistical Computing, Vienna, Austria.

Riisgård, H.U., others, 1988. Efficiency of particle retention and filtration rate in 6 species of Northeast American bivalves. Mar. Ecol. Prog. Ser. 45, 217-223.

Riisgård, H.U., Randløv, A., 1981. Energy budgest, growth and filtration rates in Mytilus edulis at different algal concentrations. Mar. Biol. 61, 227-234. https://doi.org/10.1007/BF00386664

Riou, V., Colaço, A., Bouillon, S., Khripounoff, A., Dando, P., Mangion, P., Chevalier, E., Korntheuer, M., Connelly, D., Serrao Santos, R., others, 2010. Mixotrophy in the deep sea: a dual endosymbiotic hydrothermal mytilid assimilates dissolved and particulate organic matter. Mar. Ecol. Prog. Ser. 405, 187-201.

Riou, V., Halary, S., Duperron, S., Bouillon, S., Elskens, M., Bettencourt, R., Santos, R., Dehairs, F., Colaço, A., 2008. Influence of $\mathrm{CH} 4$ and $\mathrm{H} 2 \mathrm{~S}$ availability on symbiont distribution, carbon assimilation and transfer in the dual symbiotic vent mussel Bathymodiolus azoricus. Biogeosciences 5, 1681-1691.

Salerno, J.L., Macko, S.A., Hallam, S.J., Bright, M., Won, Y.-J., McKiness, Z., Van Dover, C.L., 2005. Characterization of symbiont populations in life-history stages of mussels from chemosynthetic environments. Biol. Bull. 208, 145-155.

Sarradin, P.-M., Cannat, M., 2015. MOMARSAT2015 cruise, RV Pourquoi pas ?

Sarradin, P.-M., Cannat, M., 2014. MOMARSAT2014 cruise, RV Pourquoi pas ?

Sarradin, P.-M., Caprais, J.-C., Riso, R., Kerouel, R., Aminot, A., 1999. Chemical environment of the hydrothermal mussel communities in the Lucky Strike and Menez Gwen vent fields, Mid Atlantic ridge. Cah. Biol. Mar. 40, 93-104.

Sarradin, P.-M., Sarrazin, J., 2006. MOMARETO cruise, RV Pourquoi pas ?

Sarrazin, J., Juniper, S.K., Massoth, G., Legendre, P., 1999. Physical and chemical factors influencing species distributions on hydrothermal sulfide edifices of the Juan de Fuca Ridge, northeast Pacific. Mar. Ecol. Prog. Ser. 190, 89-112.

Sarrazin, J., Legendre, P., de Busserolles, F., Fabri, M.-C., Guilini, K., Ivanenko, V.N., Morineaux, M., Vanreusel, A., Sarradin, P.-M., 2015. Biodiversity patterns, environmental drivers and indicator species on a high-temperature hydrothermal edifice, Mid-Atlantic Ridge. Deep Sea Res. Part II Top. Stud. Oceanogr., Exploring New Frontiers in Deep-Sea Research: In Honor and Memory of Peter A. Rona 121, 177-192. https://doi.org/10.1016/j.dsr2.2015.04.013

Sarrazin, J., Rodier, P., Tivey, M.K., Singh, H., Schultz, A., Sarradin, P.M., 2009. A dual sensor device to estimate fluid flow velocity at diffuse hydrothermal vents. Deep Sea 
Res. Part Oceanogr. Res. Pap. 56, 2065-2074.

https://doi.org/10.1016/j.dsr.2009.06.008

Scott, K.M., Cavanaugh, C.M., 2007. CO2 Uptake and Fixation by Endosymbiotic

Chemoautotrophs from the Bivalve Solemya velum. Appl. Environ. Microbiol. 73,

1174-1179. https://doi.org/10.1128/AEM.01817-06

Shillito, B., Bris, N.L., Hourdez, S., Ravaux, J., Cottin, D., Caprais, J.-C., Jollivet, D., Gaill, F., 2006. Temperature resistance studies on the deep-sea vent shrimp Mirocaris fortunata. J. Exp. Biol. 209, 945-955. https://doi.org/10.1242/jeb.02102

Soetaert, K., Herman, P.M.J., 2008. A Practical Guide to Ecological Modelling: Using R as a Simulation Platform. Springer Science \& Business Media.

Soetaert, K., Petzoldt, T., 2010. Inverse Modelling, Sensitivity and Monte Carlo Analysis in R Using Package FME. J. Stat. Softw. 33, 1-28.

Soetaert, K., Petzoldt, T., Setzer, W., 2010. Solving Differential Equations in R: Package deSolve. J. Stat. Softw. 33, 1-25.

Speakman, J.R., 2005. Body size, energy metabolism and lifespan. J. Exp. Biol. 208, 17171730. https://doi.org/10.1242/jeb.01556

Streams, M.E., Fisher, C.R., Fiala-Médioni, A., 1997. Methanotrophic symbiont location and fate of carbon incorporated from methane in a hydrocarbon seep mussel. Mar. Biol. 129, 465-476. https://doi.org/10.1007/s002270050187

Szafranski, K.M., Piquet, B., Shillito, B., Lallier, F.H., Duperron, S., 2015. Relative abundances of methane- and sulfur-oxidizing symbionts in gills of the deep-sea hydrothermal vent mussel Bathymodiolus azoricus under pressure. Deep Sea Res. Part Oceanogr. Res. Pap. 101, 7-13. https://doi.org/10.1016/j.dsr.2015.03.003

Thompson, R.J., Bayne, B.L., 1972. Active metabolism associated with feeding in the mussel Mytilus edulis L. J. Exp. Mar. Biol. Ecol. 9, 111-124. https://doi.org/10.1016/0022$0981(72) 90011-1$

Trask, J.L., Van Dover, C.L., 1999. Site-specific and ontogenetic variations in nutrition of mussels (Bathymodiolus sp.) from the Lucky Strike hydrothermal vent field, MidAtlantic Ridge. Limnol. Oceanogr. 44, 334-343. https://doi.org/10.4319/lo.1999.44.2.0334

Tsurumi, M., Tunnicliffe, V., 2001. Characteristics of a hydrothermal vent assemblage on a volcanically active segment of Juan de Fuca Ridge, northeast Pacific. Can. J. Fish. Aquat. Sci. 58, 530-542. https://doi.org/10.1139/f01-005

Tunnicliffe, V., Embley, R.W., Holden, J.F., Butterfield, D.A., Massoth, G.J., Juniper, S.K., 1997. Biological colonization of new hydrothermal vents following an eruption on Juan de Fuca Ridge. Deep Sea Res. Part Oceanogr. Res. Pap. 44, 1627-1644. https://doi.org/10.1016/S0967-0637(97)00041-1

Turner, F.B., 1970. The Ecological Efficiency of Consumer Populations. Ecology 51, 741742. https://doi.org/10.2307/1934059

Vahl, O., 1973. Pumping and oxygen cunsumption rates of Mytilus edulis L. of different sizes. Ophelia 12, 45-52. https://doi.org/10.1080/00785326.1973.10430118

Van Dover, C.L., Desbruyères, D., Segonzac, M., Comtet, T., Saldanha, L., Fiala-Medioni, A., Langmuir, C., 1996. Biology of the Lucky Strike hydrothermal field. Deep Sea Res. Part Oceanogr. Res. Pap. 43, 1509-1529. https://doi.org/10.1016/S09670637(96)00051-9

Welch, H.E., 1968. Relationships between Assimiliation Efficiencies and Growth Efficiencies for Aquatic Consumers. Ecology 49, 755-759. https://doi.org/10.2307/1935541

Widdows, J., 1978. Physiological indices of stress in Mytilus edulis. J. Mar. Biol. Assoc. U. K. $58,125-142$.

Widdows, J., 1973. Effect of temperature and food on the heart beat, ventilation rate and oxygen uptake of Mytilus edulis. Mar. Biol. 20, 269-276. https://doi.org/10.1007/BF00354270

Widdows, J., Fieth, P., Worrall, C.M., 1979. Relationships between seston, available food and feeding activity in the common mussel Mytilus edulis. Mar. Biol. 50, 195-207. https://doi.org/10.1007/BF00394201 
